\title{
DA RESTITUIÇÃO DO PREÇO FACE ÀS ALTERAÇÕES DE VALOR DA COISA EVICTA*
}

\author{
PRICE REPAYMENT CONCERNING THE ALTERATIONS OF VALUE OF THE THING IN CASE OF \\ EVICTION
}

Sergio Tuthill Stanicia**

\begin{abstract}
Resumo:
O art. 450, parágrafo único, do Código Civil de 2002, determina que o preço da coisa evicta será restituído pelo alienante com base no valor da coisa à época da eviç̧ão. O objetivo deste trabalho é analisar criticamente esse dispositivo, tendo em vista que o Código Civil de 1916, no seu art. 1.109, determinava simplesmente a restituição integral do preço pago. O tema tem especial importância se tivermos em conta que, entre o momento da aquisição da coisa e o momento da evicção, o bem evicto pode ter sofrido mudanças de valor, dando ensejo a consideráveis alterações quanto ao montante a ser restituído.
\end{abstract}

Palavras-chave: Evicção. Restituição do preço. Alterações de valor. Inflação. Deterioração.

\begin{abstract}
:
The article 450, paragraph, of the 2002 Brazilian Civil Code establishes that the price repaid by the seller must correspond to the value of the thing at the time of eviction. Our purpose is to analyse this aspect critically, because the article 1.109 of the 1916 Brazilian Civil Code simply determined that the seller was due to refund the full price that was paid. The subject is especially important due to the fact that it is possible for the value of the thing to suffer alterations from the time the contract is concluded until eviction takes place, which can consequently alter considerably the amount due to the buyer.
\end{abstract}

Keywords: Eviction. Price repayment. Alterations of value. Inflation. Deterioration.

1. Introdução

O objetivo deste artigo é analisar a conveniência da alteração legislativa consubstanciada no art. 450, parágrafo único, do Código Civil de 2002, que modificou o sistema de cálculo da restituição do preço no caso da indenização pela eviç̧ão consagrado no art. 1.109 do Código Civil de 1916. Como veremos, tal alteração legislativa está diretamente relacionada ao problema das mudanças de valor da coisa evicta, e à ponderação acerca de qual interesse será mais merecedor de tutela - o do alienante, ou o do adquirente.

Este artigo foi parcialmente baseado em Tese de Láurea realizada no Departamento de Direito Civil da Faculdade de Direito da Universidade de São Paulo.

* Aluno do Curso de Pós-Graduação stricto sensu da Faculdade de Direito da Universidade de São Paulo. Bacharel em Direito pela Universidade de São Paulo, com periodo acadêmico na Universidade de Roma II - Tor Vergata. 
Para enfrentarmos tais questões, primeiramente traçaremos algumas considerações gerais sobre a responsabilidade pela evicção, que têm por objetivo esclarecer porque a indenização é tratada legislativamente, e deve ser tratada doutrinariamente, de modo separado da indenização pelo inadimplemento culposo das obrigações. Em seguida, traçaremos um breve panorama das posições doutrinárias e jurisprudenciais acerca do tema no Brasil e trataremos do problema da desvalorização da moeda e sua relação com a valorização da coisa. Será necessário cuidar brevemente também das benfeitorias, que acarretam um aumento de valor da coisa. Quanto à proteção dos interesses, quer do alienante, quer do adquirente, será interessante analisar doutrina e legislação estrangeira para verificar se é relevante a posição subjetiva do alienante - conforme esteja de boa ou má-fé, tenha agido com culpa ou dolo, ou sem culpa ou dolo. Por fim, trataremos do problema da deterioração do bem evicto, e da sua relação com as possíveis desvalorizações que independam de degradação material.

Em suma, pretendemos com este artigo contribuir minimamente para o debate acerca da mudança quanto ao critério de restituição do preço da coisa evicta. A responsabilidade pela evicção é um tema indubitavelmente clássico, que continua consagrado nas legislações civis da família romano-germânica. Apesar disso, verifica-se que atualmente poucos autores debruçam-se sobre o tema. Com o advindo do Código de Defesa do Consumidor - Lei 8.078/90 - o estudo do instituto-irmão, por assim dizer, da evicção - o dos vícios redibitórios - parece ter ganhado novo fôlego. O mesmo, todavia, não aconteceu com o nosso instituto, o que levou a alteração legislativa de que trataremos a passar um tanto quanto despercebida. Assim, mais do que chegar a conclusões, nosso objetivo com este trabalho é propor questionamentos e instigar o debate, destacando alguns pontos que talvez ainda não tenham sido tratados com a devida profundidade.

\section{Considerações gerais}

A evicção é normalmente definida pela doutrina brasileira como a perda total ou parcial de uma coisa, em virtude de uma sentença judicial que a atribui a um terceiro que demonstra ter sobre essa coisa um direito anterior à sua alienação.' $\mathrm{A}$ finalidade da responsabilidade pela evicção é assegurar proteção ao adquirente quando

Cf. entre outros BEVILÁQUA, Clóvis. Código civil dos Estados Unidos do Brasil comentado. 6. ed. Rio de Janeiro: Francisco Alves, 1946. v. 4. p. 378; SANTOS, João Manuel de Carvalho. Código Civil brasileiro interpretado. 7. ed. Rio de Janeiro - São Paulo: Freitas Bastos, 1964. v. 15. p. 378; PEREIRA, Caio Mário da Silva. Instituições de direito civil: Contratos. Declaração unilateral de vontade. Responsabilidade civil. 12. ed. atual. por Regis Fichtner. Rio de Janeiro: Forense, 2006. v. 3. p. 135-6; e RODRIGUES, Sílvio. Direito civil: dos contratos e das declarações unilaterais de vontade. 30. ed. São Paulo: Saraiva, 2007. v. 3. p. 113. 
este, por iniciativa de um terceiro, for privado do direito alienado. Na realidade, constitui uma fase cronologicamente sucedânea à alienação da coisa alheia. ${ }^{2}$

A responsabilidade pela evicção vem desde o direito romano, ${ }^{3}$ e está consagrada na maior parte dos Códigos Civis da família romano-germânica. Atualmente, encontra-se disciplinada no Códigos Civis italiano, francês, argentino e espanhol, entre muitos outros. O Código Civil alemão - o Bürgerliches Gesetzbuch (BGB) - não tem uma disciplina jurídica específica. A justificativa da doutrina é que a responsabilidade por vício de direito não é vista como consequência de um dever legal especial de garantia, mas como parte do cumprimento do contrato. Conseqüentemente, está sujeita às regras sobre inadimplemento das obrigações nos contratos bilaterais, previstas nos $\S \S 320$ a $327 .{ }^{4}$

Também o Código Civil português de 1966 não disciplinou o instituto da evicção, que estava presente no Código antigo, de 1867. Alguns autores, aliás, aplaudem o fato de que teria sido "definitivamente eliminado" do direito português o "velho sistema" herdado do direito romano. ${ }^{5}$ Todavia, a legislação portuguesa, como veremos, traz uma disciplina própria para a venda de coisa alheia, a partir do art. $892^{\circ}$. O Código Civil italiano, aliás, consagra, lado a lado, a disciplina da venda de coisa alheia e da garantia contra evicção. As regras disciplinadoras das verbas devidas ao adquirente, inclusive, são praticamente as mesmas (art. $1479,2^{\circ}$ e $3^{\circ}$ co.). Tanto é assim, que autores questionam a conveniência da manutenção da disciplina jurídica da evicção, pois talvez ela fosse uma "supergaranzia" um excesso de tutela do comprador que só seria explicável no sistema de separação entre os planos dos direitos obrigacionais e dos direitos reais, e não no sistema do consenso translativo. ${ }^{6}$

Relevante, neste ponto, é atentar para o fato de que esses Códigos Civis consagram diferentes sistemas para a transferência da propriedade. O direito alemão segue a orientação romana da separação de planos, em que a compra e venda tem efeitos meramente obrigacionais e a transferência da propriedade - eficácia real - fica na dependência de um acordo de transmissão posterior e abstrato. Trata-se do chamado "princípio da separação absoluta entre os planos" Já no direito francês, italiano e português, entre outros, é o

2 Cf. LUMINOSO, Angelo. Vendita. In: Digesto delle discipline privatistiche: sezione civile. Torino: UTET, 1999. v. 19. p. 640-1 e DELOGU, Lucia. La vendita. In: VISINTINI, Giovanna (Org.). Trattato della responsabilità contrattuale. Padova: CEDAM, 2009. v. 2. p. 121.

3 Para a evicção no direito romano, bem como bibliografia suplementar, ver TALAMANCA, Mario. Vendita (diritto romano). In: Enciclopedia del diritto. Milano: Giuffrè, 1993. v. 46. p. 378-93 e 435-7.

4 Cf. ENNECCERUS, Ludwig. Derecho de obligaciones. In: ENNECCERUS, Ludwig; KIPP, Theodor; e WOLFF, Martin. Tratado de derecho civil. Trad esp. por Blás Péres Gonzáles e José Alguer. Barcelona: Bosch, 1935. v. 2. p. 44-5; e LARENZ, Karl. Derecho de obligaciones. Trad esp. por Jaime Santos Briz. Madrid: Revista de Derecho Privado, 1959. t. 2. p. 46-8.

5 Cf. LIMA, Fernando Andrade Pires de; e VARELA, João de Matos Antunes. Código civil anotado: artigos $762^{\circ}$ a $1250^{\circ}$ 4. ed. Coimbra: Coimbra, 1997. v. 2. p. 184.

6 Cf. DE MARTINI, Angelo. Evizione (diritto civile). In: Novissimo digesto italiano. Torino: UTET, 1957. v. 6. p. 1053. 
próprio consenso no contrato que provoca a transferência da propriedade, no chamado efeito translativo, consagrado, por exemplo, no art. 1376 do Código Civil italiano. ${ }^{7}$ O direito brasileiro adota o sistema da separação relativa, que não é tão rígido quanto o alemão, mas ainda assim exige um acordo de transferência de propriedade posterior para ser obtido o efeito real. ${ }^{8}$

Em relação ao problema da restituição do preço, de que trataremos neste artigo, não terá tanta importância essa diferenciação entre os sistemas. Tanto é assim que o Código Civil italiano determina o mesmo sistema de indenização, quer para a evicção, quer para a venda de coisa alheia (cf. arts. 1479 e 1483). O que deve ser apontado é que essa disciplina especial para a venda de coisa alheia acaba sendo consequência da adoção do sistema do consenso translativo. Como é o próprio contrato que transfere a propriedade, considera-se necessária a tutela do comprador mesmo antes de vir a ocorrer a evicção. Tanto é assim, que o Código Civil português não disciplinou expressamente a responsabilidade pela evicção, e adotou, assim como o Código Civil francês, o princípio da nulidade da venda de coisa alheia. ${ }^{9}$

Quanto ao enquadramento sistemático da garantia contra a evicção, é mais usual nos Códigos a sua inserção na disciplina do contrato de compra e venda. Todavia, mesmo nos países em que isso ocorre, ${ }^{10}$ é amplamente reconhecida a sua aplicabilidade a outros contratos de alienação. ${ }^{1}$ Um possível argumento de defesa da disciplina da responsabilidade pela evicção dentro do contrato de compra e venda, é que uma disciplina mais genérica no âmbito dos contratos onerosos daria ensejo a tantas exceções e restrições, que seria mais seguro deixar ao intérprete a decisão sobre a conveniência da sua aplicação por analogia a outros contratos. ${ }^{12}$

7 "Contratto con effetti reali. - Nei contratti che hanno per oggetto il trasferimento della proprietà di una cosa determinata, la costituzioni o il trasferimento di un diritto reale ovvero il trasferimento di un altro diritto, la proprietà o il diritto si trasmettono e si acquistano per effetto del consenso delle parti legittimamente manifestato."

8 Cf. COUTO E SILVA, Clóvis. A obrigação como processo. reimpr. Rio de Janeiro: FGV, 2006. p. 49-52.

9 Isso está no art. 1599 do Código Civil francês, que estabelece que "la vente de la chose d'autrui est nulle", bem como no art. $892^{\circ}$ do Código Civil português, que prescreve: "é nula a venda de bens alheios sempre que o vendedor careça de legitimidade para a realizar". Ao contrário do Código português, o francês, mais antigo e fiel à tradição, manteve a disciplina da evicção apesar de consagrar a nulidade da venda de coisa alheia.

10 A título de exemplo, os Códigos Civis francês, italiano, espanhol, o Código Suíço das Obrigações, e até o Código Comercial brasileiro de 1850 - atualmente não mais em vigência nessa parte - tratam da responsabilidade pela eviç̧ão dentro da disciplina da compra e venda.

1 Cf. BIANCA, Cesare Massimo. La vendita e la permuta. In: VASSALLI, Filippo (Org.). Trattato di diritto civile italiano. Torino: UTET, 1972. v. 7. t. 1. p. 621; CHIANALE, Angelo. Evizione. In: Digesto delle discipline privatistiche: sezione civile. Torino: UTET, 1998. v. 8. p. 166. DE MARTINI, Angelo. op. cit. p. 1070, afirma que "in relazione al diritto moderno, l'orientamento dominante è nel senso della estensione dell'istituto a tutti i contratti a prestazioni corrispettive".

12 Cf. RICCA-BARBERIS, Mario. Trattato della garanzia per evizione: parte generale. Torino: Giappicchelli, 1958. p. 41. 
Contrariando a colocação tradicional, o nosso Código Civil cuida do tema na parte geral dos contratos, como já o fazia o Código Civil de 1916, determinando a aplicabilidade das regras a todos os contratos onerosos (art. 447). Assim, a responsabilidade pela evicção é sistematicamente tratada na Parte Especial, Livro I - Do Direito das Obrigações, Título V - Dos contratos em geral, Capítulo I - Disposições gerais, Seção VI - Da evicção, que abrange os art. 447 a 457. Semelhante era a orientação do Código Civil de 1916, que tratava sistematicamente do tema nos arts. 1.107 a 1.117. Não obstante o trato no âmbito dos contratos onerosos, o Código Civil de 2002, como já o fazia o Código de 1916, refere-se à eviç̧ão também em outros dispositivos (arts. 359, 552, 845, $1.005,1.937$, inciso III, e 2.024 a 2.026). Esses artigos dizem respeito, respectivamente, à dação em pagamento, à doação, à transação, às sociedades personificadas e à garantia dos quinhões hereditários. Note-se, portanto, que a ocorrência da responsabilidade pela evicção não se restringe ao campo dos contratos onerosos, embora seja nesse que o instituto encontra uma disciplina jurídica sistemática.

Em relação à natureza jurídica, muitos autores falam em obrigação de garantia. ${ }^{13}$ "Garantia" é um termo polissêmico, que pode ser genericamente entendido como "todo meio destinado a render mais seguro o gozo de um direito ou o adimplemento de uma obrigação" No caso da evicção, bem como dos vícios redibitórios, o garante assume um risco contratual, assegurando a fruição pacífica ou útil de um bem. ${ }^{14}$ Obrigação de garantia é aquela cuja prestação não consiste em um comportamento, mas na assunção de um risco. Consequentemente, o garante obriga-se independentemente de culpa. ${ }^{15}$

Outros autores, todavia, afirmam que garantia indicaria um dado subjetivo, que determina a medida do poder de agressão de algum credor sobre os bens do devedor em contraposição ao poder dos outros credores. Seria errado, portanto, falar em obrigação de garantia, e mais adequado falar apenas em responsabilidade. Isso porque responsabilidade referir-se-ia a um elemento objetivo - a sujeição dos bens do devedor às razões do credor. ${ }^{16}$

13 Cf. COMPARATO, Fábio Konder. Obrigações de meio, de resultado e de garantia. In: Ensaios e pareceres de direito empresarial. Rio de Janeiro: Forense, 1978. p. 538-9; PEREIRA, Caio Mário da Silva. op. cit. v. 3. p. 139; SANTOS, João Manuel de Carvalho. op. cit. v. 15. p. 382-3; DI MAJO, Adolfo. Responsabilità contrattuale. In: Digesto delle discipline privatistiche: sezione civile. Torino: UTET, 1998. v. 17. p. 50-1; e GALGANO, Francesco. Vendita (diritto privato). In: Enciclopedia del diritto. Milano: Giuffrè, 1993. v. 46. p. 491. Nós falaremos de garantia contra a evicção, como o faz a maioria da doutrina e o Código Civil, que aliás, refere-se à "responsabilidade pela evicção" (art. 448) também como "garantia contra a eviç̧ão" (arts. 447 e 449$)$.

14 Cf. TUCCI, Giuseppe. Garanzia. In: Digesto delle discipline privatistiche: sezione civile. Torino: UTET, 1992. v. 8. p. 581-2.

is Cf. GALGANO, Francesco. op. cit. v. 46. p. 491

16 Cf. MESSINEO, Francesco. Manuale di diritto civile e commerciale: codici e norme complementari. 8. ed. Milano: Giuffrè, 1954. v. 3. p. 68-9. DE MARTINl, Angelo. op. cit. p. 1055, afirma que "non si tratta, allora, nè di responsabilità per inadempimento, e nemmeno di 'garanzia' in senso proprio. Si tratta, invece, di una responsabilità che l'ordinamento giuridico adossa in linea obiettiva al venditore" 
Não obstante essa discussão, nós falaremos indiferentemente de garantia contra a evicção e de responsabilidade pela evicção. É o que faz o nosso Código Civil, que usa o primeiro termo, por exemplo, nos arts. 447 e 449 e o segundo no art. 448.

Apesar de presente na doutrina a posição segundo a qual, em caso de evicção, estaríamos diante de inadimplemento obrigacional, é prevalente o entendimento de que essa noção não se aplica ao nosso caso. ${ }^{17} \mathrm{~F}$. C. Pontes de Miranda, aliás, entende que como a coisa é efetivamente prestada, não há um inadimplemento, mas um adimplemento ruim. A prestação efetivamente é adimplida, mas o que há é um adimplemento que desaparece no futuro, que vem a perder-se. Assim, a pretensão ao ressarcimento só surgirá se ocorrer o fato da evicção, ou seja, se o bem gravado de vício jurídico efetivamente perder-se em favor do terceiro. ${ }^{18}$

A consequência mais importante do fato de que a eviç̧ão não deve ser considerada inadimplemento obrigacional, é que a indenização ao adquirente calcular-se-á de maneira diversa. Como estamos diante de uma espécie de responsabilidade objetiva, em que o devedor responde independentemente de culpa, ${ }^{19}$ não se justifica uma indenização ampla e completa das perdas e danos, como ocorreria no caso de estarmos diante de um efetivo inadimplemento obrigacional culposo. A responsabilidade pela evicção não cai na vala comum da disciplina jurídica de toda e qualquer indenização por inexecução contratual. ${ }^{20} \mathrm{O}$ alienante não tem o dever de ressarcir o adquirente completamente e, por isso, a recuperação do prejuízo é delimitada na lei e compreende a restituição do preço e algumas indenizações. ${ }^{21}$

3. Estado atual da legislação, doutrina e jurisprudência brasileiras

Nessa linha de raciocínio, as verbas devidas ao evicto são previstas no art. 450 do Código Civil de 2002 - correspondente ao art. 1.109 do Código Civil de 1916 - e

17 BIANCA, Cesare Massimo. La vendita e la permuta cit. p. 638-9 e p. 622-5, defende que a evicção dá ensejo ao inadimplemento obrigacional, mas ele próprio reconhece que o seu posicionamento é minoritário. Caterina MIRAGLIA. Divisione contrattuale e garanzia per evizione. Napoli: ESI, 1981. p. 164-5, por exemplo, entende ser ultrapassada a ideia da eviç̧ão como inadimplemento. Também excluem a ideia de inadimplemento, por exemplo, DI MAJO, Adolfo. Responsabilità contrattuale cit. p. 50-1; DE MARTINI, Angelo. op. cit. p. 1.055 .

18 Cf. MIRANDA, Francisco Cavalcanti Pontes de. Tratado de direito privado: parte especial. reimpr. atual. por Vilson Rodrigues Alves. Campinas: Bookseller, 2005. t. 38. p. 201-2.

19 Cf. DI MAJO, Adolfo. Responsabilità contrattuale cit. p. 50-1, e COMPARATO, Fábio Konder. op. cit. p. 538-9.

20 Cf. MAZEAUD, Henri; MAZEAUD, Léon; e MAZEAUD, Jean. Leçons de droit civil: principaux contrats. 4. ed. par Michel de Juglart. Paris: Montchrestien, 1974. t. 3, v. 2. p. 234; PLANIOL, Marcel; e RIPERT, Georges. Traité pratique de droit civil français: contrats civils: première partie. 2. ed. par Joseph Hamel (vente); François Givord et André Tunc (louage). Paris: LGDJ, 1956. t. 10. p. 122.

21 Cf. GOMES, Orlando. Contratos. 26. ed. atual. por Antonio Junqueira de Azevedo e Francisco Paulo De Crescenzo Marino. Rio de Janeiro: Forense, 2007. p. 117; e DE MARTINI, Angelo. op. cit. p. 1.053. 
nos arts. 453 e 454 - antigos arts. 1.113 e 1.114 do velho Código. Conforme as regras especiais da indenização pela evicção, o evicto, além da restituição do preço, tem direito a receber o valor dos frutos que teve de pagar ao terceiro; as despesas com o contrato; as custas judiciais e honorários advocatícios; os prejuízos diretamente resultantes da evicção; e o valor das benfeitorias necessárias e úteis não abonadas a ele. ${ }^{22}$

Quanto ao preço pago, dispunha o art. 1.109 do Código Civil de 1916 que, salvo disposição em contrário, o evicto teria direito à sua restituição integral. ${ }^{23} \mathrm{O}$ art. 450 do novo Código repetiu a redação do Código de 1916 em seu caput, mas estabeleceu em seu parágrafo único que o preço, seja no caso de evicção total, seja no caso de evicção parcial, será o do valor da coisa na época em que se evenceu e proporcional ao desfalque sofrido no caso de evicção parcial. ${ }^{24}$

Essa talvez seja a principal alteração que sofreu a disciplina da responsabilidade pela evicção no novo diploma civil. Nesse ponto, o novo Código difere muito do antigo, pois o art. 1.109 do Código de 1916 dava a entender que a restituição seria a do preço pago, e não a do preço correspondente ao valor da coisa na época da evicção. Este último entendimento estava previsto expressamente somente para o caso de evicção parcial, no art. 1.115. ${ }^{25}$ O Código de 2002 unificou os dois sistemas, estabelecendo que em ambos os casos, o que deve ser levado em conta é o valor da coisa no momento da evicção.

Sob a égide do Código Civil de 1916, discutia-se o fato de que o legislador, ao determinar a restituição do preço pago, descuidara da possibilidade da coisa estar

22. Essa sistematização, com base na letra da lei, das verbas devidas em cinco tópicos é feita por DALLAGNOLO, Dorval Baptista. Da evicção na compra e venda imobiliária. Tese (Doutorado). Faculdade de Direito da Universidade de São Paulo, 1993. p. 82-5.

23 "Art. 1.109. Salvo estipulação em contrário, tem direito o evicto, além da restituição integral do preço, ou das quantias, que pagou: I - à indenização dos frutos que tiver sido obrigado a restituir; II - à das despesas dos contratos e dos prejuizos que diretamente resultarem da evicção; III - às custas judiciais."

24 "Art. 450. Salvo estipulação em contrário, tem direito o evicto, além da restituição integral do preço ou das quantias que pagou: I - à indenização dos frutos que tiver sido obrigado a restituir; II - à indenização pelas despesas dos contratos e pelos prejuízos que diretamente resultarem da evicção; III - às custas judiciais e aos honorários do advogado por ele constituído. Parágrafo único. O preço, seja a evicção total ou parcial, será o do valor da coisa, na época em que se evenceu, e proporcional ao desfalque sofrido, no caso de eviç̧ão parcial."

25 "Art. 1.115. A importância do desfalque, na hipótese do artigo antecedente, será calculada em proporção do valor da coisa ao tempo em que se evenceu." Clóvis BEVILÁQUA justificava o sistema diferenciado para a eviç̧ão parcial, pois dizia que a parte do preço correspondente ao desfalque sofrido calculada pelo valor da coisa ao tempo da evicção era o que expressava verdadeiramente qual fora o prejuízo do adquirente. Afirmava que se fosse aplicado o mesmo princípio da eviç̧ão total, a restituição seria complicada e não tornaria a regra melhor nem do ponto de vista da lógica, nem da justiça. Concluía que, quer na evicção total, quer na parcial, o que se buscava era ressarcir o dano que o evicto sofrera. Esse dano, no caso da parcial, seria exatamente o que o adquirente perdera no momento da eviç̧ão (op. cit. v. 4. p. 277-8). Já Francisco Cavalcanti PONTES DE MIRANDA afirmava que o regime diferenciado era uma exceção apenas aparente, pois o Código não dizia que a indenização passava a ser pelo valor do momento em que ocorresse a evicção, apenas que a proporção seria tomada nesse momento (op. cit. t. 38. p. 255-6). 
valorizada entre o momento da alienação e o da evicção. Nesse caso, o evicto verse-ia desprotegido, uma vez que receberia a restituição de um preço menor do que o correspondente ao valor atual da coisa. Para solucionar o problema, a doutrina ${ }^{26}$ e a jurisprudência, ${ }^{27}$ de um modo geral, passaram a entender que, não obstante a redação do art. 1.109, a restituição do preço deveria ocorrer com base no valor da coisa ao tempo em que se evenceu. Entendia-se que o fundamento legal da solução preconizada era o inciso II do art. 1.109, que determinava a indenização genérica dos prejuízos diretamente resultantes da evicção. Se a coisa, por outro lado, estivesse desvalorizada entre o momento da aquisição e o da evicção, essa diminuição de valor não seria levada em conta, uma vez que a restituição deveria ser integral do preço pago. ${ }^{28}$

Não-obstante o entendimento consagrado pela doutrina, o Código Civil de 2002 procurou resolver legislativamente o problema da valorização da coisa (art. 450, parágrafo único). A nova solução, todavia, vem recebendo críticas, pois o Código Civil, buscando resolver o problema da falta de proteção do evicto no caso da valorização da

26 Cf. GONDIM, Regina Bottentuit. Da eviç̧ão. 1955. Tese (Cátedra) Faculdade de Direito de Niterói, Niterói. p. 78-9; MONTEIRO, Washington de Barros. Curso de direito civil: direito das obrigações: $2^{\mathrm{a}}$ parte. 34. ed. atual. por Carlos Alberto Dabus Maluf e Regina Beatriz Tavares da Silva. São Paulo: Saraiva, 2003. v. 5. p. 58-9; SOUZA, Sebastião de. Da compra e venda. 2. ed. Rio de Janeiro: Forense, 1955. p. 294; PEREIRA, Caio Mário da Silva. op. cit. v. 3. p. 140; e MIRANDA, Francisco Cavalcanti Pontes de. op. cit. t. 38. p. 316-23.

27 Em especial, era o entendimento da Terceira Turma do Superior Tribunal de Justiça. Ver, a propósito, os seguintes acórdãos: Recurso Especial 3.056/RJ, rel. Min. Nilson Naves, j. 28/06/1990, DJ 20/08/1990, p. 7965. Ementa: "EVICÇÃO TOTAL. RESPONSABILIDADE DO ALIENANTE. RESTITUIÇÃO DO PREÇO (CCV, ART. 1.109). PELA PERDA SOFRIDA, TEM O EVICTO DIREITO A RESTITUIÇÃO DO PREÇO PELO VALOR DO BEM AO TEMPO EM QUE DELE DESAPOSSADO; AO TEMPO EM QUE SE EVENCEU. RECURSO ESPECIAL CONHECIDO PELO DISSIDIO E PROVIDO"; RecursO Especial 132.012/SP, rel. Min. Waldemar Zveiter, j. 05/11/1998, DJ 24/05/1999, p. 161. Ementa: "CIVIL VENDA E COMPRA DE IMÓVEL - EVICÇÃO PERDAS E DANOS PRESCRIÇ̃̃O DA AÇÃO INOCORRÊNCIA RESPONSABILIDADE DO ALIENANTE PELA EVICÇ̃̃O PRETENSÃO DE ISENÇÃO BASEADA EM DISPOSITIVOS SOBRE OS QUAIS O ACÓRDÃO NÃO SE PRONUNCIOU

FALTA DE PREQUESTIONAMENTO(SÚMULAS 282 E 356/STF) VALOR A SER RESTITUÍDO (art. 1.109 do CC) I É de direito pessoal a prescrição que atinge contrato (escritura) de venda e compra de imóvel, quando verificado que o vendedor não porta título de propriedade, eis que decisão judicial anterior entre partes que não os da avença, decretou-lhe a eviç̧ão. Precedente da Corte. II Responsabilidade pela evicção, cuja isenção se propugna, à luz de dispositivos acerca dos quais o Acórdão hostilizado nada deliberou, nem houve provocação, pela via dos declaratórios. Falta de prequestionamento que inviabiliza a apreciação da matéria em sede de Especial (Súmulas 282 e 356/STF). III - A orientação jurisprudencial desta Terceira Turma é no sentido de que, pela perda sofrida, tem o evicto direito à restituição do preço, pelo valor do bem ao tempo em que dele desapossado, ou seja, ao tempo em que se evenceu. IV Recurso Especial de que não se conhece"; e Recurso Especial 134.412/GO, rel. Min. Waldemar Zveiter, j. 19/11/1998, DJ 01/02/1999, p. 184. Ementa: "CIVIL - EVICÇÃO TOTAL - INDENIZAÇĀO. I - Dispondo o artigo 1115, do Código Civil, que se a eviç̧ão for parcial a indenização é tomada na proporção do valor da coisa ao tempo em que se evenceu, é incompreensível que o mesmo Código não agasalhe idêntico critério para o caso de evicção total. II - Precedentes. III - Recurso conhecido em parte e, nessa parte, provido."

28 Cf. LEMOS, Patrícia Faga Iglecias. O instituto da eviç̧ão à luz do Código Civil brasileiro e do projeto de Código Civil (634-B/75). Revista do Instituto de Pesquisa e Estudos, Bauru, n. 24. dez./mar. 1998-1999. p. 237; DALLAGNOLO, Dorval Baptista. op. cit. p. 84; e PEREIRA, Caio Mário da Silva. op. cit. v. 3 p. 140. 
coisa, teria criado um problema inverso. Agora, o evicto ver-se-ia privado de tutela no caso de ter havido desvalorização do bem entre o momento da aquisição e o da evicção. ${ }^{29}$

Por conta disso, Jones Figueirêdo Alves ofereceu ao Deputado Ricardo Fiúza uma proposta de alteração do parágrafo único do art. 450, que foi incorporada ao Projeto de Lei 6.960/02. ${ }^{30}$ Trata-se de um duplo critério de aferição do preço, criado a partir de um julgado do Superior Tribunal de Justiça. ${ }^{31}$ Segundo o projeto, o parágrafo passaria a ter a seguinte redação: “O preço, seja a evicção total ou parcial, será o do valor da coisa, na época em que se evenceu, e proporcional ao desfalque sofrido, no caso de evicção parcial, salvo na hipótese de valor pago a maior ao tempo da alienação ou em valor necessário que propicie ao evicto adquirir outro bem equivalente"

A proposta, todavia, recebeu duras críticas no Parecer Vicente Arruda. Entendeu-se que deveria ser mantida a redação atual do artigo, pois a nova introduziria uma contradição entre os critérios de aferição do preço. Como no início do parágrafo manda-se restituir o preço aferido de determinada maneira e ao final diz-se que a restituição pode fazer-se de duas outras formas, na prática, "chega-se a um non sequitor, pois não se fica sabendo qual o valor a ser pago pela evicção" 32

Esse é, em síntese, o quadro atual da legislação, doutrina e jurisprudência brasileiras. Passaremos agora a analisar algumas questões que não são tratadas aprofundadamente pela maioria dos autores, mas que têm extrema relevância para o nosso problema.

\section{Desvalorização da moeda}

Quando falamos em valor de determinado bem, precisamos ter em mente a ideia da Economia enquanto ciência. Esta tem lugar porque as necessidades dos seres humanos são em grande número e expandem-se indefinidamente. Por outro lado, os recursos para o atendimento dessas necessidades são escassos, limitados e finitos. Como os bens são úteis e escassos, associa-se a eles um valor, que corresponde à sensação de perda provocada pela sua destruição ou desaparição. Esse valor comporta duas dimensões. A primeira é o valor de uso, que diz respeito à utilidade do bem para determinado indivíduo

29 Cf. LEMOS, Patrícia Faga Iglecias. op. cit. p. 249-51.

30 Cf. ALVES, Jones Figueirêdo. In: FIÚZA, Ricardo. Novo Código Civil comentado. 2. ed. São Paulo: Saraiva, 2003. p. 404-5.

31 Superior Tribunal de Justiça, Terceira Turma, Recurso Especial 248.423/MG, rel. Min. Eduardo Ribeiro, j. 27/04/2000, DJ 19/06/2000, p. 146. Ementa: "Indenização. Perdas e danos. Evicção. Perdida a propriedade do bem, o evicto há de ser indenizado com importância que lhe propicie adquirir outro equivalente. Não constitui reparação completa a simples devolução do que foi pago, ainda que com correção monetária"

32 Apud DINIZ, Maria Helena. Curso de direito civil brasileiro: teoria das obrigações contratuais e extracontratuais. 22. ed. São Paulo: Saraiva, 2006. v. 3. p. 139-40. 
ou grupo. A segunda é o valor de troca ou valor econômico, que diz respeito a uma projeção objetiva e impessoal do bem no âmbito da sociedade. ${ }^{33}$

Com o surgimento da moeda, que nada mais é do que um instrumento de troca, ${ }^{34 / 35}$ aparece a noção de preço. Este "nada mais vem a ser do que o valor econômico expresso em unidades monetárias e quantificado por elas de tal sorte que quando dois bens apresentam o mesmo preço, eles podem tranquilamente ser permutados, pois terão o mesmo valor" ${ }^{36}$ Sendo o preço uma expressão monetária, sua restituição nada mais é do que uma obrigação pecuniária, que é aquela que tem por objeto uma prestação em dinheiro. Trata-se de um tipo particular de obrigação de dar que, devido a importantes peculiaridades, merece tratamento especial. A moeda pode ter diferentes valores. $\mathrm{O}$ valor nominal é "aquele com que as espécies monetárias são postas a circular e que trazem, em regra, inscrito sobre cada uma delas" Já o valor aquisitivo da moeda, ou valor de troca interno, é "a quantidade de mercadorias que, em dado momento, se pode adquirir com a espécie monetária considerada".37

$\mathrm{O}$ art. 315 do Código $\mathrm{Civil}^{38}$ consagra o princípio nominalista ou do nominalismo, prevendo que as dívidas em dinheiro deverão ser pagas em moeda corrente e pelo seu valor nominal. ${ }^{39}$ Este é o que se encontra impresso na cédula. O sistema é justificável pela dificuldade de se fixar o coeficiente de valorização ou desvalorização da

33 Cf. NUSDEO, Fabio. Curso de economia: introdução ao direito econômico. 3. ed. São Paulo: Revista dos Tribunais, 2001. p. 28 e 44.

34 Com efeito, afirmam MARTY, Gabriel; RAYNAUD, Pierre; JESTAZ, Phillipe. Les obligations: le régime. 2. ed. Paris: Sirey, 1989. t. 2. p. 9, que: "la monnaie est une mésure des valeurs et si cette monnaie est instable, elle cesse d'exprimer la véritable valeur des biens qu'elle permet de se procurer et on est conduit à rechercher cette valeur à travers une expression monétaire imparfait et changeante afin d'éviter la détérioration de certaines créances résultant de la dévaluation monétaire"

35 Sobre a importância da moeda, destaca MOSCO, Luigi. Gli effetti giuridici della svalutazione monetaria. Milano: Giuffrè, 1948. p. 49, que: "il denaro nell' assetto economico moderno, ha acquistato una cosi ampia diffusione come mezzo di scambio da sostituire quasi del tutto i corrispettivi in natura, ed inoltre che esso è quasi l'unico mezzo di pagamento giuridicamente riconosciuto"

36 Cf. NUSDEO, Fábio. op. cit. p. 50.

37 Cf. VARELA, João de Matos Antunes. Das obrigações em geral. 10. ed. Coimbra: Almedina, 2000. v. 1. p. 845, 848 e 850. Ver também GOMES, Orlando. Obrigações. 16. ed. atual. por Edvaldo Brito. Rio de Janeiro: Forense, 2005. p. 55.

38 Segundo INZITARI, Bruno. Il principio nominalistico. In: INZITARI, Bruno; VISENTINI, Gustavo; DI AMATO, Astolfo. Moneta e valuta. In: GALGANO, Francesco. Trattato di diritto commerciale e di diritto pubblico dell'economia. Padova: CEDAM, 1983, v. 6. p. 70; e SCADUTO, Gioacchino. I debiti pecuniari e il deprezzamento monetario. Milano: Valardi, 1924. In: PALAZZO, Antonio (a cura di). Gioacchino Scaduto - Diritto civile: opere monografiche. Perugia: Dipartimento per gli studi giuridici Alessandro Giuliani, 2002. t. 1. p. 388, o princípio do nominalismo é uma constante nos sistemas jurídicos contemporâneos. MOSCO, Luigi. op. cit. p. 49, aliás, sobre o tema, destaca que "quando un medesimo principio giuridico diventa comune a molte legislazioni ciò basta già a significare ch'esso tende a soddisfare un'esigenza razionale della vita sociale"

39 Segundo BIANCA, Cesare Massimo. Diritto civile: I’obbligazione. Milano: Giuffrè, 1993. v. 4. p. 147, “in senso specifico esso è la regola secondo la quale le obbligazioni pecuniarie si eseguono in conformità del loro importo nominale" 
moeda sem uma boa dose de arbítrio. É o critério mais cômodo e seguro. Porém, como no nominalismo o credor suporta o risco da desvalorização da moeda ${ }^{40} \mathrm{em}$ determinadas situações o fenômeno da inflação atinge uma gravidade tal que a legislação cria exceções a esse princípio. ${ }^{41}$ É o que ocorreu no Brasil, no qual o princípio da correção monetária através das chamadas cláusulas de escala móvel praticamente se generalizou ${ }^{42} \mathrm{~A}$ inflação é "um processo de aumento contínuo e generalizado nos níveis de preço" Em especial entre o final da década de setenta e a implantação do Plano Real, em 1994, os índices inflacionários subiram modo assustador. Em março de 1990, com um índice de 84\%, o Brasil esteve à beira da hiperinflação. ${ }^{43}$

A correção monetária foi oficializada como padrão de atualização dos valores contratuais já a partir dos anos sessenta, mas ainda era tratada com reserva pela jurisprudência e pela doutrina. Todavia, com o passar do tempo - e conforme os índices de inflação subiam - começou a ser vista como a expressão absoluta do justo contratual. ${ }^{44}$ Isso, logicamente, deu ensejo a uma série de problemas. A atualização monetária dos valores era incerta, pois se fazia com uma série de índices distintos, públicos e privados, baseados em parâmetros diferentes. Havia o agravante de que a inflação em determinados setores era diferente de outros, o que tornava imprecisa a aplicação do mesmo índice de correção monetária. Além disso, a correção monetária revelou-se um fator decisivo de realimentação da inflação..$^{45}$

Apesar de todas essas vicissitudes, bem como da drástica diminuição dos índices de inflação após o Plano Real, verifica-se na prática que a correção monetária está generalizada no nosso país. A Lei n. 10.192/01, apesar de consagrar o princípio do nominalismo e limitar o uso da correção monetária (art. $1^{\circ}$ ), admite expressamente sua

40 Cf. GOMES, Orlando. Obrigações cit. p. 55-8; BIANCA, Cesare Massimo. Diritto civile cit. v. 4. p. 148. Sobre o princípio do nominalismo no direito francês, bem como sua relação com a possibilidade de depreciação da moeda, ver GHESTIN, Jacques; BILLIAU, Marc. Le prix dans les contrats de longue durée. Paris: LGDJ, 1990. p. 73.

41 João Baptista Villela ensina que o nominalismo tem, "em períodos de instabilidade monetária, um alto preço: a quebra do equilíbrio das prestações, o rompimento da justiça comutativa, a desgraça do credor ou do devedor" (VILLELA, João Baptista. Contribuição à teoria do valor dos bens na colação hereditária. 1964. Tese (Livre-Docência) - Universidade de Minas Gerais, Belo Horizonte. p. 38).

42 Cf. LÔBO, Paulo Luiz Netto. In: AZEVEDO, Antonio Junqueira de (Coord.). Comentários ao Código Civil: parte especial: das várias espécies de contratos (arts. 481 a 564). São Paulo: Saraiva, 2003. v. 6. p. 44-5; GOMES, Orlando. op. cit. p. 58-9; e VARELA, João de Matos Antunes. op. cit. v. 1. p. 854-5.

43 Cf. LANZANA, Antonio Evaristo Teixeira. Economia brasileira: fundamentos e atualidade. 2. ed. São Paulo: Atlas, 2002. p. 105 e 115-23.

44 Para um histórico da generalização da utilização da correção monetária no Brasil, ver: WALD, Arnoldo. Tullio Ascarelli, o direito monetário e o direito bancário (uma visão brasileira inspirada no Código Civil). In: AZEVEDO, Antonio Junqueira de; TÔRRES, Heleno Taveira; e CARBONE, Paolo (Coord.). Principios do novo Código Civil brasileiro e outros temas: homenagem a Tullio Ascarelli. São Paulo: Quartier Latin, 2008. p. 93-99.

45 LÔBO, Paulo Luiz Netto. op. cit. v. 6, p. 45. 
utilização, observados determinados requisitos $\left(\operatorname{art.} 2^{\circ}\right)$. Para o efeito que nos interessa, a Lei n. 6.899/81, regulamentada pelo Decreto 86.649/81, determina a aplicação de correção monetária aos débitos oriundos de decisão judicial. ${ }^{46}$

É importante fazer essas considerações, pois é relativamente comum a confusão entre a questão das alterações de valor entre o momento da aquisição da coisa e o momento da evicção com o fenômeno da desvalorização da moeda, isto é, da inflação. ${ }^{47}$

Dentre os doutrinadores, Sílvio Rodrigues citava como exemplo de valorização da coisa a aquisição de um prédio em 1950 por trezentos cruzeiros, que em função da inflação teria passado a valer três mil em 1960. Para o autor, não seria justo o adquirente receber apenas os trezentos cruzeiros que pagara, como supostamente determinaria o art. 1.109 do Código Civil de 1916 ao falar na restituição integral do preço ou das quantias pagas. ${ }^{48} \mathrm{Na}$ mesma linha, Sebastião de Souza, exemplificava com o caso de uma pessoa que adquirira por cinco mil cruzeiros um terreno que, dez anos depois, teria passado a valer cinco ou seis vezes mais. Caso lhe fosse restituído apenas o preço que pagara, seu patrimônio ficaria desfalcado. ${ }^{49}$

A jurisprudência também já incorreu no mesmo equívoco. O Min. Dias Trindade já afirmou em voto que "os prejuízos que se indenizam, na ocorrência de evicção, se compõem com os decorrentes da inflação, que determinam a desvalorização da moeda, de modo a expressar em outros números o valor do bem ao tempo em que se evenceu" 50 Também o Min. Carlos Alberto Menezes Direito, em voto divergente, defendeu a solução de restituir-se o preço correspondente ao valor da coisa na época da eviç̧ão como forma de indenizar os prejuízos sofridos em decorrência da inflação. ${ }^{53}$

46 Cf. PEREIRA, Caio Mário da Silva Pereira, Instituições de direito civil: teoria geral das obrigações. 21. ed. atual. por Guilherme Calmon Nogueira da Gama. Rio de Janeiro: Forense, 2008. v. 2. p. 160; e GOMES, Orlando. Obrigações cit., p. 59, nt. 9.

47 Cf. VARELA, João de Matos Antunes. op. cit. v. 1. p. 853.

48 Cf. RODRIGUES, Sílvio. op. cit. v. 3. p. 119-20.

49 Cf. SOUZA, Sebastião de. op. cit. p. 295.

so Superior Tribunal de Justiça, Quarta Turma, Recurso Especial 39.347/SC, rel. Min. Dias Trindade, j. 23/11/1993, DJ 07/02/1994, p. 1188. Ementa: "CIVIL. EVICÇÃO. INDENIZAÇÃO. COMPOSIÇÃO. OS PREJUIZOS QUE SE INDENIZAM, NA OCORRENCIA DE EVICÇÃO, SE COMPOEM COM OS DECORRENTES DA INFLAÇÃO, QUE DETERMINAM A DESVALORIZAÇÃO DA MOEDA, DE MODO A EXPRESSAR EM OUTROS NUMEROS O VALOR DO BEM AO TEMPO EM QUE SE EVENCEU."

s1 Superior Tribunal de Justiça, Terceira Turma, Recurso Especial 132.012/SP, rel. Min. Waldemar Zveiter, j. 05/11/1998, DJ 24/05/1999, p. 161. Ementa: "CIVIL - VENDA E COMPRA DE IMÓVEL - EVICÇÃO

PERDAS E DANOS PRESCRIÇÃO DA AÇÃO INOCORRÊNCIA RESPONSABILIDADE DO ALIENANTE PELA EVICÇÃO - PRETENSÃO DE ISENÇÃO BASEADA EM DISPOSITIVOS SOBRE OS QUAIS O ACÓRDÃO NÃO SE PRONUNCIOU - FALTA DE PREQUESTIONAMENTO(SÚMULAS 282 E 356/STF) - VALOR A SER RESTITUÍDO (art. 1.109 do CC) I - É de direito pessoal a prescrição que atinge contrato (escritura) de venda e compra de imóvel, quando verificado que o vendedor não porta titulo de propriedade, eis que decisão judicial anterior entre partes que não os da avença, decretou-lhe a evicção. Precedente da Corte. Il Responsabilidade pela evicção, cuja isenção se propugna, à luz de dispositivos 
O raciocínio desses autores era no sentido da injustiça da solução preconizada pelo art. 1.109 do Código Civil de 1916. Tratavam do problema da valorização do bem de um ponto de vista meramente nominalista, sem atentar para a utilização de qualquer índice de correção monetária. Nessa linha, inexoravelmente haveria sempre valorização entre o momento da aquisição da coisa e o momento da eviç̧ão, devido aos altos índices de inflação que tivemos. Tanto é assim, que Sílvio Rodrigues justifica o fato do Código de 1916 referir-se ao valor que fora pago pela coisa com a época de relativa estabilidade econômica em que vivera o legislador. Por isso, este não poderia ter antevisto os graves problemas de uma época de inflação elevada. ${ }^{52}$

O fato é que, com a generalização da correção monetária, as hipóteses levantadas por esses autores nunca se concretizariam. $O$ preço pago pela coisa não seria restituído ao adquirente pelo valor nominal, mas seria aplicada a correção monetária para suprir a desvalorização da moeda. O preço continuaria a ser aquele pago por ocasião do contrato, uma vez que haveria uma mera atualização do valor da moeda. Não haveria, portanto, contrariedade à letra do art. 1.109 do Código Civil de 1916, pois não se trata do montante correspondente ao valor da coisa na época da eviç̧ão.

O verdadeiro problema da valorização da coisa não tem a ver com a desvalorização da moeda, mas com o momento em que se afere o valor da coisa. Abstraindose do fenômeno da inflação, existe a possibilidade de que o preço pago por ocasião do contrato, mesmo atualizado monetariamente, não corresponda ao preço correspondente ao valor da coisa na época da evicção. Pode ocorrer que a coisa em si tenha sofrido alteração de valor, independentemente do fenômeno da desvalorização da moeda.

Essa separação conceitual é minuciosamente explicitada por Fábio Nusdeo, ao afirmar que "qualquer variação de preços apontada ou discutida não decorrerá de fenômenos puramente monetários, tais como inflação ou deflação, mas única e exclusivamente de causas mercantis, ou seja, maior ou menor escassez dos bens, variações na sua oferta e procura ou causas institucionais, quando fixados por uma autoridade" Em seguida, o autor afirma que "quando se falar em preços, eles serão sempre tidos como reais, vale dizer, já depurados ou deflacionados para eliminar toda e qualquer interferência de índole monetária. E sempre, é claro, considerando os preços como quantificações em unidade monetária do valor econômico dos bens - o seu valor de troca" ${ }^{53}$

acerca dos quais o Acórdão hostilizado nada deliberou, nem houve provocação, pela via dos declaratórios. Falta de prequestionamento que inviabiliza a apreciação da matéria em sede de Especial (Súmulas 282 e 356/STF). III - A orientação jurisprudencial desta Terceira Turma é no sentido de que, pela perda sofrida, tem o evicto direito à restituição do preço, pelo valor do bem ao tempo em que dele desapossado, ou seja, ao tempo em que se evenceu. IV - Recurso Especial de que não se conhece"

52 Cf. RODRIGUES, Sílvio. op. cit. v. 3. p. 119.

53 Cf. NUSDEO, Fábio. op. cit. p. 53. 
Nesse sentido, existe uma espécie de obrigação pecuniária, cujo objeto não é propriamente a entrega de um preço pré-fixado, mas de um montante em dinheiro variável, pois correspondente a uma certa coisa ou ao custo real e mutável de determinado objeto. O dinheiro nada mais é do que um ponto de referência, uma medida do valor de uma coisa. ${ }^{54}$ Trata-se dos chamados débitos de valor, ${ }^{55}$ cujo principal expoente e teorizador foi Tullio Ascarelli. ${ }^{56} \mathrm{O}$ grande problema dessas obrigações é saber o momento específico em que se deve fixar o montante, pois a quantia devida é determinada tendo em vista sua correspondência com o valor de determinada coisa. ${ }^{57}$ Essa categoria, de aceitação controversa, por exemplo, em Portugal, é amplamente aplicável ao direito brasileiro. ${ }^{58}$

Não é nosso objetivo neste artigo tratar extensamente das dívidas de valor. Mencionamos o assunto, pois ele é relevante para depurar a interpretação do problema da restituição do preço na evicção dos equívocos já referidos. Como a obrigação do alienante restituir o preço pago cai no âmbito das dívidas de valor, ${ }^{59}$ a legislação deve estabelecer se o montante corresponderá ao valor da coisa na época da alienação - o preço pago, que poderá ser corrigido monetariamente - ou ao valor da coisa na época da evicção. Dessa forma, o art. 450, parágrafo único, ao determinar a restituição do preço da coisa à época da evicção, não se refere ao preço pago pela coisa na época do contrato, atualizado monetariamente, como poderia pensar um intérprete mais desavisado. Refere-

54 Cf. VARELA, João de Matos Antunes. op. cit. v. 1. p. 858-9. Segundo ASCARELLI, Tullio. Studi giuridici sulla moneta. Milano: Giuffrè, 1952. p. 94, "la somma di moneta [...] costituirà solo il mezzo per la liquidazione del debito, non il suo oggetto"

s5 Para BIANCA, Cesare Massimo. Diritto civile cit. v. 4. p. 149, "debiti di valore sono i debiti pecuniari determinabili esclusivamente in ragione di un dato valore economico"

s6 "Il riferimento è, senza dubbio, all'Ascarelli, que può considerarsi il 'padre della suddetta categoria", cf. GUIDA, Giovanni. et. al. Le obbligazioni pecuniarie. In: PATTI, Salvatore; e VACCA, Letizia. Trattato delle obbligazioni: le figure speciali. Padova: CEDAM, 2010. v. 5. p. 195. Ver também RIZZO, Nicola. Il problema dei debiti di valore. Padova: CEDAM, 2010. p. 4. Cf. ASCARELLI, Tullio. Obbligazioni pecuniarie: art. 1277-1284. In: SCIALOJA, Antonio; e BRANCA, Giuseppe. Commentario del Codice Civile: libro quarto - delle obbligazioni. Bologna: Foro Italiano, 1959. p. 172.

57 Cf. ANTUNES VARELA, João de Matos. op. cit. v. 1. p. 860. Segundo ASCARELLI, Tullio. Studi giuridici sulla moneta cit. p. 93, "La somma di moneta corrispondente a questo valore (nell'ipotesi di oscillazioni monetarie) potrà essere diversa, secondi i vari momenti, e potrà perciò esser diversa secondochè si consideri il momento in cui si è costituito il debito, quello della domanda giudiziale, quello della sentenza, e via di seguito".

58 Cf. WALD, Arnoldo. Tullio Ascarelli cit. p 93-5; WALD, Arnoldo. A cláusula de escala móvel. São Paulo: Max Limonad, 1956. p. 68. Com relação à aceitação da categoria nos diferentes ordenamentos jurídicos, DI MAJO, Adolfo. Obbligazioni pecuniarie. In: Enciclopedia del diritto. Milano: Giuffrè, 1979. v. 29. p. 261-2, afirma que o instituto é amplamente aceito na Alemanha, mas encontra maior resistência no direito francês. Já na Itália, a categoria desenvolveu-se principalmente por obra da jurisprudência.

59 WALD, Arnoldo. Direito das obrigações: teoria geral das obrigações e contratos civis e comerciais. 15. ed. atual. por Semy Glanz. São Paulo: Malheiros, 2001. p. 283, expressamente qualifica a indenização decorrente da evição como dívida de valor. Para BIANCA, Cesare Massimo. Diritto civile cit. v. 4. p. 152, não é outro o entendimento da jurisprudência italiana quanto à obrigação oriunda da alienação de coisa alheia. 
se, com efeito, ao montante correspondente ao valor da coisa na época da evicção, que, obviamente, poderá ser igual, maior ou menor que o montante pago.

\section{Valorização decorrente de benfeitorias}

Uma outra confusão que deve ser dirimida é aquela entre a valorização da coisa pura e simples e aquela decorrente de benfeitorias feitas pelo adquirente. $O$ problema da valorização da coisa de que tratamos não diz respeito àquele aumento de valor que decorre de melhoramentos realizados na coisa ${ }^{60}$ Isso porque, para o caso de benfeitorias, o nosso Código Civil traz uma disciplina toda própria. Assim como os frutos, as benfeitorias também são tidas pela doutrina como bens acessórios. Esse enquadramento, todavia, recebe duras críticas de F. C. Pontes de Miranda, para quem as benfeitorias "em princípio, não são acessórios (posto que a meia ciência o diga e repita), porque são partes integrantes" Para o autor, "as benfeitorias são o que faz bem, por ser necessário, ou útil, ou de maior deleite ou recreio, ao imóvel ou ao móvel" ${ }^{61}$

Já segundo a clássica definição atribuída a Clóvis Beviláqua, benfeitorias são obras ou despesas feitas na coisa, com o fim de conservá-la, melhorá-la ou embelezála. ${ }^{62}$ Essas três finalidades - conservar, melhorar e embelezar - dizem respeito aos três tipos de benfeitorias consagradas pelo Código Civil no seu art. 96. ${ }^{63} \mathrm{O}$ Código estabelece que as benfeitorias podem ser necessárias, úteis ou voluptuárias, que se destinam respectivamente a conservar, melhorar e embelezar o bem principal. Nas palavras do Código, as benfeitorias necessárias são as que visam a conservar o bem ou evitar que ele se deteriore. As úteis são as que aumentam ou facilitam o uso do bem. As voluptuárias, de acordo com o $\S 1^{\circ}$ do art. 96 , são "as de mero deleite ou recreio, que não aumentam o uso habitual do bem, ainda que o tornem mais agradável ou sejam de elevado valor"

60 RUBINO, Domenico. La compravendita. In: CICU, Antonio; e MESSINEO, Francesco. Trattato di diritto civile e commerciale. 2. ed. Milano: Giuffrè, 1971. v. 23. p. 367, diferencia o caso em que "la cosa è aumentata di valore ma non per effetto di migliorie apportatele dal compratore (ad es., per apertura di una contigua strada camionale, che valorizza il fondo)"

${ }_{61}$ Cf. MIRANDA, Francisco Cavalcanti Pontes de. op. cit. t. 38. p. 331.

62 Cf. PEREIRA, Caio Mário da Silva. Instituições de direito civil: introdução ao direito civil; teoria geral do direito civil. 21. ed. atual. por Maria Celina Bodin de Moraes. Rio de Janeiro: Forense, 2005. v. 1. p. 437-8; AMARAL, Francisco. Direito civil: introdução. 6. ed. Rio de Janeiro: Renovar, 2006. p. 331; MONTEIRO, Washington de Barros. Curso de direito civil: direito das coisas. 38. ed. atual. por Carlos Alberto Dabus Maluf. São Paulo: Saraiva, 2007. v. 3.p. 63.

63 Segundo MENEZES CORDEIRO, António. Tratado de direito civil português: I - Parte geral - Coisas (incluindo domínio público, energia, teoria da empresa e tutela dos animais). 2. ed. Coimbra: Almedina, 2002. t. 2. p. 175 , a tripartição das benfeitorias vem desde o direito romano, e foi sempre adotada pela doutrina portuguesa ao longo da História. 
Essa classificação das benfeitorias em três categorias será muito importante para a disciplina jurídica dos efeitos da posse. ${ }^{64} \mathrm{~A}$ disciplina jurídica das benfeitorias aplicada à posse de boa-fé e à posse de má-fé está nos arts. 1.219 a 1.222 do Código. Prevê o art. 1.219 que o possuidor de boa-fé tem direito a ser indenizado das benfeitorias necessárias e úteis, podendo inclusive exercer o direito de retenção sobre elas. Quanto às benfeitorias voluptuárias, se elas não the forem indenizadas, o possuidor de boa-fé as poderá levantar, se não houver detrimento da coisa. $O$ art. 1.222 prevê que, no caso da posse de boa-fé, o que o reivindicante terá que indenizar ao possuidor é sempre o valor atual das benfeitorias. Em relação à posse de má-fé, o possuidor somente tem direito a ser indenizado pelas benfeitorias necessárias. Além disso, o possuidor de má-fé não tem direito de retenção, nem direito de levantar as benfeitorias voluptuárias - ius tollendi (art. $1.220){ }^{65}$

Quanto à indenização pelas benfeitorias em caso de evicção, o nosso Código Civil a disciplina expressamente nos arts. 453 e 454, que têm a mesma redação dos arts. 1.112 e 1.113 do Código Civil de 1916. Preveem os dispositivos que o evicto receberá do alienante o valor das benfeitorias necessárias e úteis que não lhe forem abonadas. Além disso, na restituição devida será levado em conta o valor das benfeitorias feitas pelo alienante.

O primeiro ponto que merece ser destacado é que, se o evicto foi indenizado pelo terceiro, nenhuma pretensão tem de exigir o valor das benfeitorias do alienante. Tudo vai depender da boa-fé ou da má-fé do adquirente em relação ao terceiro. Se o adquirente estiver de má-fé, não tem direito a receber do terceiro as benfeitorias úteis nem as voluptuárias que realizou, por força do art. 1.220. Dessa forma, como o art. 453 manda que o alienante indenize ao adquirente as benfeitorias úteis e necessárias que não foram ressarcidas pelo terceiro, o evicto tem o direito de receber o valor das benfeitorias úteis do alienante. Quanto às benfeitorias necessárias, o possuidor de má-fé tem direito de se ressarcir junto ao terceiro. Dessa forma, nenhuma pretensão surge contra o alienante. ${ }^{66 / 67}$

${ }_{64} \dot{E}$ interessante notar, quanto ao direito italiano, segundo BARBA, Angelo. Spese (diritto privato). In: Enciclopedia del diritto. Milano: Giuffrè, 1990. v. 43. p. 325-6, que se prefere o uso do termo "miglioramenti" a "spese" para indicar situações em que o aumento do valor do bem seja "causalmente connesso all 'attività del possessore", não obstante, classicamente a tripartição em úteis, necessárias e voluptuárias diga respeito às "spese" Talvez isso se deva ao fato de que o termo "spese" é usado de maneira ambígua pelo legislador de 1942. Já "miglioramento" parece ser usado com um significado mais preciso, podendo ser definido, segundo INZITARI, Bruno. Miglioramenti (diritto privato). In: Enciclopedia del diritto. Milano: Giuffrè, 1976. v. 26. p. 279, como "un aumento di utilità o di valore della cosa conseguente al compimento di un'attività su di essa"

65 Curiosa a afirmação de SACCO, Rodolfo. Il possesso. In: CICU, Antonio; MESSINEO, Francesco; e MENGONI, Luigi. Trattato di diritto civile e commerciale. Milano: Giuffrè, 1988. v. 7. p. 368, de que "il miglioramento eliminabile è una figura giuridica certo enigmatic a"

66 Cf. MIRANDA, Francisco Cavalcanti Pontes de. op. cit. t. 38. p. 333

${ }^{67}$ Para WAYAR, Ernesto. Evicción y vicios redhibitorios: Evicción en los contratos en particular. Vicios 
O conteúdo dos arts. 453 e 454 diz respeito somente à relação entre alienante e adquirente, e não entre adquirente e evictor. Assim, não tem nenhuma relação com o disposto nos arts. 1.219, 1.220 e 1.222. Estes artigos pautam-se pela boa-fé ou máfé do evicto. Estas, na relação entre adquirente e alienante, só serão pertinentes para se averiguar a existência da pretensão à responsabilidade pela evicção - por força do art. 457 , que veda a quem sabia ser a coisa alheia ou litigiosa demandar pela evicção - e não para a determinação das verbas devidas ao evicto. ${ }^{68}$

O segundo e último ponto que merece ser destacado é o disposto no art. 454. Trata-se do caso em que as benfeitorias foram realizadas pelo alienante, antes da transferência do bem ao adquirente. Essas benfeitorias, no momento da alienação, já eram parte integrante da coisa. Pode ocorrer, todavia, que o terceiro acabe indenizando ao evicto o valor correspondente a essas benfeitorias. Nesse caso, não é justo que o alienante restitua a integralidade do preço pago ao adquirente. Portanto, o valor dessas benfeitorias - que foram indenizadas pelo terceiro ao adquirente - é descontado do preço que o alienante houver de restituir ao evicto. ${ }^{69}$

\section{Conveniência da solução legislativa}

Uma vez exposto o problema da alteração legislativa e feitas as precisões acerca da desvalorização monetária e das valorizações decorrentes de benfeitorias, passamos a analisar a conveniência das diferentes soluções, tanto do Código Civil de 1916, quanto do Código Civil de 2002.

Conforme pudemos verificar, a solução adotada pelo novo Código Civil encontra correspondência no Código Civil espanhol. O art. 1478, $1^{\circ}$ determina: "Cuando se haya estipulado el saneamiento o cuando nada se haya pactado sobre este punto, si la evicción se ha realizado, tendrá el comprador derecho a exigir del vendedor [...] la

redhibitorios. Parte general. Buenos Aires: Astrea, 1992. v. 2. p. 8, "el legislador ha dispuesto que el vendedor deduzca, de lo que debe restituir, las sumas que el comprador ya recibió; a los fines queridos por la ley, poco importa que esas sumas provengan del evincente (triunfador en el juicio).

Cf. MIRANDA, Francisco Cavalcanti Pontes de. op. cit. t. 38. p. 334. É interessante notar que no sistema francês, a boa-fé ou má-fé do alienante importa na sua relação com o adquirente, na medida em que são devidos os valores das benfeitorias voluptuárias se o alienante estiver de má-fé. Estabelece o art. 1635 que: "Si le vendeur avait vendu de mauvaise foi le fonds d'autrui, il sera obligé de rembourser à l'acquéreur toutes les dépenses, même voluptuaires ou d'agrément, que celui-ci aura faites au fonds." Cf. SAVATIER, René. Cours de droit civil. 2. ed. Paris: LDGJ, 1949. t. 2. p. 337; JOSSERAND, Louis. Cours de droit civil positiffrançais: Théorie générale des obligations. Les principaux contrats du droit civil. Les suretés. 2. ed. Paris: Sirey, 1933. t. 2. p. 583. Aliás, afirmam PLANIOL, Marcel; RIPERT, Georges. op. cit. p. 123: "La mauvaise foi du vendeur n'accroûtra donc sa responsabilité de garantie que dans la mesure très minime expressément prévue par l'art. 1635 à propos des impenses" Já o nosso Código Civil, nesse ponto, fala apenas das benfeitorias úteis e necessárias, excluindo as voluptuárias mesmo no caso em que o alienante estiver de boa-fé.

69 Cf. MIRANDA, Francisco Cavalcanti Pontes de. op. cit. t. 38. p. 333. 
restitución del precio que tuviere la cosa vendida al tiempo de la evicción, ya sea mayor o menor que el de la venta" É interessante notar, que para evitar qualquer polêmica, a legislação espanhola é mais explícita que a nossa, pois coloca expressamente que o valor não se alterará seja ele maior, seja ele menor.

Apesar disso, a solução da restituição do preço pago é mais presente nas legislações estrangeiras. ${ }^{70} \mathrm{E}$ comum, todavia, haver uma previsão legislativa expressa para o caso de ter havido valorização da coisa. A falta de um dispositivo equivalente ao art. 1633 do Código Civil francês no nosso Código de 1916, aliás, era inclusive lamentada por autores pátrios. ${ }^{71}$ Prevê esse dispositivo: "Si la chose vendue se trouve avoir augmenté de prix à l'époque de l'éviction, indépendamment même du fait de l'acquéreur, le vendeur est tenu de lui payer ce qu'elle vaut au-dessus du prix de la vente" 72 É o que dispõe também o art. 2121 do Código Civil argentino. ${ }^{73}$

É interessante que, no Brasil, o Esboço do Código Civil de Augusto Teixeira de Freitas adotava solução semelhante. Após prever que o vendedor responderia pela restituição do preço (art. 3538), o Esboço estabelecia que na indenização pelas perdas e interesses prevista nesse mesmo dispositivo entraria toda a diferença para mais entre o preço da venda e o valor da coisa no dia da evicção (art. 3542). ${ }^{74}$ Se o nosso Código Civil de 1916 tivesse incorporado essa previsão, o problema não teria dado ensejo a tanta polêmica no Brasil.

É de se ressaltar, contudo, que mesmo nos países em que há previsão expressa para o caso de valorização da coisa, a solução não é isenta de problemas quando se está diante de alienações sucessivas, em que o valor da coisa vai progressivamente aumentando ou diminuindo. A doutrina entende que, em ambos os casos, não pode o evicto exigir mais do que pagou ao último alienante. ${ }^{75 / 76}$ Assim, hipoteticamente, suponhamos

70 A solução é explícita, por exemplo, nos Códigos Civis argentino e italiano, e implícita nos Códigos Civis francês e português. O art. 2118 do argentino determina que "verificada la evicción, el vendedor debe restituir al comprador el precio recibido por él". Pelo art. $1479,2^{\circ}$ co., do italiano, "il venditore è tenuto a restituire all'acquirente il prezzo pagato". Menos explícito, o francês fala apenas que "si l'acquéreur est évincé, il a droit de demander contre le vendeur [...] la restitution du prix". Por fim, o português, quanto à venda de bem alheio, fala em "restituição integral do preço" (art. 894, $\mathrm{n}^{\circ} 1$ ).

71 Cf. GONDIM, Regina. op. cit. p. 78; e SOUZA, Sebastião de. op. cit. p. 294.

72 Para SAVATIER, René. op. cit. t. 2. p. 336, o Código Civil francês traz uma forte proteção para o adquirente, pois este terá sempre direito ao valor mais alto da coisa.

73 "El importe de los daños y perjuicios sufridos por la evicción, se determinará por la diferencia del precio de la venta con el valor de la cosa el día de la evicción, si su aumento no nació de causas extraordinarias"

74 Cf. FREITAS, Augusto Teixeira de. Esboço do Código Civil. 3. ed. Brasília: Ministério da Justiça, 1983. v. 2. p. 522.

75 Cf. GONÇALVES, Luiz da Cunha. Da compra e venda no direito comercial brasileiro. 2. ed. São Paulo: Max Limonad, 1950. p. 422; MAZEAUD, Henri. et al. op. cit. p. 233; PLANIOL, Marcel; e RIPERT, Georges. op. cit. p. 121.

76 Com relação ao direito argentino, esclarece WAYAR, Ernesto. op. cit. p. 4, que: "no interesa que en operaciones anteriores el precio haya sido distinto, mayor o menor, el evicto siempre limitará su pretensión 
que Caio alienou coisa alheia a Tício por R\$100,00; e Tício alienou-a a Mévio por R\$ 150,00. Mévio, evicto, poderá exigir de Tício os $\mathrm{R} \$ 150,00$; mesmo que este tenha pagado somente $\mathrm{R} \$ 100,00$ a Caio. O prejuízo que Tício teve no valor de $\mathrm{R} \$ 50,00$, todavia, poderá ser exigido de Caio, uma vez que a coisa já era alheia à época da primeira alienação. ${ }^{77}$ No caso da situação inversa, em que Caio alienou por $\mathrm{R} \$ 150,00$; e Tício alienou por $\mathrm{R} \$$ 100,00; Mévio só poderá exigir os $\mathrm{R} \$ 100,00$ que pagou a Tício, mesmo sendo valor menor do que o pago por este a Caio.

Ainda com relação às alienações sucessivas, ou "vendite a catene" é interessante destacar que o Código Civil de 2002 dispõe que o adquirente pode denunciar a lide quer ao alienante imediato, quer a qualquer um dos anteriores (art. 456). No sistema do Código Civil de 1916 (art. 1.116), entendia-se que o adquirente só podia exercer seu direito em relação ao alienante imediatamente anterior. Este, portanto, tinha que denunciar a lide ao seu alienante, e assim sucessivamente. ${ }^{78}$ Todavia, segundo o posicionamento fixado no Enunciado 29 da I Jornada de Direito Civil ${ }^{79}$, a nova redação possibilita ao evicto cobrar a indenização diretamente do responsável pelo vício jurídico, através da chamada denunciação da lide per saltum. Assim, no nosso exemplo, Mévio poderia acionar diretamente Caio pela evicção. Para outros autores, todavia, a permissão da denunciação da lide per saltum seria apenas aparente. $\mathrm{O}$ art. 456 nada mais teria feito do que legitimar a possibilidade de denunciação sucessiva, já admitida pelo art. 73 do Código de Processo Civil. $^{80}$

a la cantidad que el hubiera pagado"

77 Para RUBINO, Domenico. op. cit. p. 712-3, "nelle cosiddette vendite a catena, cioè se B, compratore, aveva rivenduto $a C$, sicchè è quest'ultimo che subisce l'evizione, $C$ può agire in garanzia, a sua scelta, contro $B$ o contro $A$, che aveva venduto a $B$; se agisce contro $B$, a questi spetta poi contro A la solita restituzione del proprio prezzo di acquisto, ma, a titolo di risarcimento del danno, gli spetta anche il rimborso dell'intera differenza fra il suo prezzo di acquisto e tutta la somma cha ha dovuto pagare a $C$ : in dettaglio, se aveva rivenduto per un prezzo maggiore gli spetta anzitutto, come mancato guadagno (lucro cessante), la differenza fra $i$ due prezzi; e oltre a ciò, o se il prezzo della rivendita non era stato maggiore, gli spetta, come danno emergente, il rimborso di tutto l'ulteriore risarcimento che a sua volta ha dovuto corrispondere a C" Cf. PEREIRA, Caio Mário da Silva. op. cit. v. 3. p. 142-3.

79 "A interpretação do art. 456 do novo Código Civil permite ao evicto a denunciação direta de qualquer dos responsáveis pelo vício". Este, aliás, é o posicionamento da doutrina italiana, cf. RUBNO, Domenico. op. cit. p. 712.

80 É a posição de YARSHELL, Flávio Luiz. Evicção e denunciação da lide no novo Código Civil: contribuição ao direito bancário. In: Revista de direito bancário e do mercado de capitais, $\mathrm{n}^{\circ} 26$, São Paulo: RT, ano 7 . out./dez. 2004. p. 37-8. 
7. Segue. Boa-fé, má-fé, dolo e culpa do alienante

É importante ressaltar que no Brasil, assim como na França ${ }^{81}$ e na Bélgica, ${ }^{82}$ é irrelevante para a responsabilização pela evicção a posição subjetiva do alienante. Posição digna de nota, apesar de absolutamente minoritária, é a de Silvio Rodrigues. Entende ele que o problema está na ponderação acerca de quem deve sofrer o prejuízo - o adquirente ou o alienante. Se ambas as partes estiverem de boa-fé, não se deve preferir o interesse do adquirente. $\mathrm{O}$ alienante de boa-fé deve reembolsar apenas o que recebeu, não se imputando a valorização da coisa nos prejuízos diretamente resultantes da evicção. ${ }^{83}$

O problema é que a opinião de Sílvio Rodrigues não encontra respaldo algum nos textos legislativos pátrios - tanto do Código Civil de 1916, quanto do atual -, que não fazem qualquer diferenciação entre o alienante e o adquirente de boa-fé ou de má-fé. As únicas considerações de ordem subjetiva feitas pelo velho Código, e também pelo novo, dizem respeito ao próprio surgimento da responsabilidade pela evicção - o evicto não pode estar de má-fé no momento da alienação (art. 1.117 do Código Civil de 1916 e art. 457 do Código Civil de 2002) - e ao caso das deteriorações da coisa por dolo do adquirente, caso em que este não receberá a totalidade da indenização (art. 1.110 do Código Civil de 1916 e art. 451 do Código Civil de 2002).

A boa-fé aqui é usada no seu sentido subjetivo. É a chamada boa-fé psicológica, que "diz respeito à tutela, em certas situações, do estado psicológico, estado de consciência caracterizado pela ignorância de se estar a lesar direitos ou interesses alheios em que pode estar um sujeito jurídico. A expressão traduz a idéia naturalista da boa-fé, aquela que, por antinomia, é conotada à má-fé e que também se manifesta pela crença injustificada na aparência de certa situação ou realidade jurídica" ${ }^{84}$ Consiste, em síntese, na ignorância pelo alienante de que a coisa alienada não lhe pertencia. A má-fé, ao contrário, consiste no conhecimento sobre a verdadeira titularidade do bem. O problema do sistema brasileiro, francês e belga, é que talvez seja excessivamente rigoroso com o alienante de boa-fé. Tanto que a maioria dos países adota um sistema diferenciado conforme o alienante esteja de boa-fé ou de má-fé.

81 Cf. MAZEAUD, Henri et al. op. cit. p. 234. PLANIOL, Marcel; RIPERT, Georges. op. cit. p. 122.

82 Cf. DE PAGE, Henri. Traité élémentaire du droit civil belge: principes - doctrine - jurisprudence. Les principaux contrats usuels (prèmiere partie). 2. ed. Bruxelles: Émile Bruylant, 1943. t. 4. p. 170.

83 Cf. RODRIGUES, Sílvio. op. cit. v. 3. p. 119-21.

84 Cf. MARTINS-COSTA, Judith. Os avatares do abuso de direito e o rumo indicado pela boa-fé. In: DELGADO, Mário Luiz; e ALVES, Jones Figueirêdo. Novo Código Civil: questões controvertidas: parte geral do Código Civil. São Paulo: Método, 2007. v. 6. p. 530. Ver também MARTINS-COSTA, Judith. $A$ boa-fé no direito privado: sistema e tópica no processo obrigacional. São Paulo: RT, 1999. p. 411-2. 
O Código Civil argentino, por exemplo, faz essa diferenciação. $O$ art. $2118^{85}$ determina genericamente ${ }^{86}$ que o alienante deve restituir ao adquirente o preço que foi recebido, sem juros. Segundo o art. $2119,{ }^{87}$ também está obrigado a pagar as custas do contrato, o valor dos frutos quando o adquirente tenha sido obrigado a restituí-los ao terceiro e os danos e prejuízos que a evicção causou ao adquirente. Conforme o art. $2121,{ }^{88}$ aliás, esse montante dos danos e prejuízos determinar-se-á pela diferença entre o preço da venda e o valor da coisa na época da evicção, desde que esse aumento de valor não tenha decorrido de causas extraordinárias ${ }^{89} \mathrm{O}$ art. $2123,{ }^{90}$ em contrapartida, dispõe expressamente que o alienante de má-fé ("mala fe") não restituirá somente o preço que recebeu e as outras indenizações, mas, no caso, o adquirente poderá optar entre receber o maior valor da coisa ou obter a restituição de todas as somas desembolsadas, ainda que sejam gastos de luxo ou mero prazer. ${ }^{91}$

Um Código Civil com uma disciplina interessante é o português de 1867, conhecido como Código de Seabra, e hoje substituído pelo diploma de 1966. A garantia contra a evicção existia também no caso do alienante estar de boa-fé, mas o regime do quantum da indenização era diferenciado. ${ }^{92}$ Segundo o art. $1047,{ }^{93}$ o alienante de boa-fé deveria restituir o preço ou aquilo que recebeu, os gastos com o contrato e com o pleito

85 "Verificada la evicción, el vendedor debe restituir al comprador el precio recibido por él, sin intereses, aunque la cosa haya disminuido de valor, sufrido deterioros o pérdidas en parte, por caso fortuito o por culpa del comprador"

86 Os arts. 2118 e 2119 não se referem expressamente ao alienante de boa-fé, mas a referência à má-fé presente no art. 2123 faz pressupor que a oposição adotada pelo Código Civil argentino seja aquela entre boa-fé e má-fé.

87 "El vendedor está obligado también a las costas del contrato, al valor de los frutos, cuando el comprador tiene que restituirlos al verdadero dueño, y a los daños y perjuicios que la evicción le causare"

88 "El importe de los daños y perjuicios sufridos por la evicción, se determinará por la diferencia del precio de la venta con el valor de la cosa el día de la evicción, si su aumento no nació de causas extraordinarias"

89 WAYAR, Ernesto. op. cit. p. 16, define como extraordinário o aumento de valor que não foi, nem poderia ser previsto pelas partes no momento da celebração do contrato. Cf. LORENZETTI, Ricardo Luis. Tratado de los contratos. Buenos Aires: Rubinzal-Culzoni, 1999. t. 1. p. 285.

90 "El vendedor de mala fe que conocía, al tiempo de la venta, el peligro de la evicción, debe a elección del comprador, o el importe del mayor valor de la cosa, o la restitución de todas las sumas desembolsadas por el comprador, aunque fuesen gastos de lujo, o de mero placer"

91 Esclarece WAYAR, Ernesto. op. cit. p. 17, que "la ley dispuso, como se ve, que si el vendedor es de mala fe, el comprador evicto tiene el derecho de optar entre reclamar el mayor valor de la cosa, o el reembolso de todas las sumas gastadas [...]. Cabe reiterar que la opción sólo se concede al comprador de buena fe. Si es de mala fe, su derecho quederá limitado a la restitución del precio"

92 Cf. CUNHA GONÇALVES, Luiz da. Tratado de direito civil: em comentário ao Código Civil português. 2. ed. [1. ed. bras.] São Paulo: Max Limonad, 1957. v. 6. t. 1. p. 38-9.

93 "O alheador, ainda que haja procedido de boa-fé, é obrigado a pagar integralmente: $1^{\circ} \mathrm{O}$ preço, ou o que haja recebido do adquirente evicto; $2^{\circ}$ Os gastos, que o mesmo adquirente tenha feito com o contrato e com o pleito da eviç̧ão, salvo a exceção do art. $1053 ; 3^{\circ}$ Todas as despesas úteis e necessárias, que não sejam abonadas ao adquirente pelo evicto ou pelo vendedor. $\S 1^{\circ}$ Se o adquirente for condenado a restituir os rendimentos, poderá exigir do alheador os interesses ou rendimentos da cousa ou soma por ele prestada. $\S 2^{\circ} \mathrm{Se} o$ adquirente não for condenado à dita restituição, reputar-se-ão compensados os rendimentos com os interesses." 
da evicção e as despesas úteis e necessárias que não foram abonadas ao adquirente. Já o alienante de má-fé, de acordo com o art. 1048, ${ }^{94}$ era responsável por todas as perdas e danos decorrentes da evicção, até mesmo pelas despesas voluptuárias. Além disso, somente o alienante de má-fé obrigava-se a pagar o valor da coisa ao tempo da evicção, se este fosse maior que o valor prestado.

Quanto ao atual Código Civil português, não há uma disciplina específica sobre a responsabilidade pela eviç̧ão, mas podemos utilizar como base de comparação a indenização pela venda de bens alheios. A diferença da lei portuguesa é que a indenização não exige a perda do bem que caracteriza a eviç̧ão, pois o comprador pode invocar a nulidade da compra e venda antes e independentemente de haver reivindicação da coisa por parte de seu verdadeiro proprietário. ${ }^{95}$ A evicção, todavia, pode ocorrer ${ }^{96}$ e a indenização não diferirá daquela pela venda de coisa alheia. Aliás, como veremos, Código Civil italiano, que disciplina tanto esta quanto a responsabilidade pela evicção, consagra expressamente para ambas o mesmo regime de indenização (arts. 1479 e 1483). ${ }^{97}$

Antes de prosseguir na análise do Código português, devemos atentar para um ponto. Até agora referimo-nos aos conceitos de boa-fé e má-fé. Contudo, ao observar-se a redação do Código Civil português de 1966, vemos que nos arts. $898^{\circ}$ a $900^{\circ}$ o legislador utiliza a palavra "boa-fé" em oposição às palavras "dolo" e "culpa". A oposição causa estranheza, pois é intuitivo que o oposto de boa-fé seja má-fé, e não o dolo ou a culpa. Segundo o Código português, a restituição do preço também é devida no caso em que o comprador estiver de "boa-fé" Todavia, este só pode pedir aquilo com que o vendedor se locupletou. Diz o art. $898^{\circ}$ que "se um dos contratantes houver procedido de boa-fé e o outro dolosamente, o primeiro tem direito a ser indenizado, nos termos gerais, de todos os prejuízos", ${ }^{98}$ Já o art. $899^{\circ}$ prevê que a indenização é devida ao "comprador de boa-fé, ainda que [o vendedor] tenha agido sem dolo nem culpa" mas compreenderá "apenas os danos emergentes que não resultem de despesas voluptuárias"

Da análise desses dispositivos, observa-se uma confusão terminológica entre as noções de dolo, culpa e má-fé. Essa confusão é relativamente comum. Caio Mário

94 "Se o alheador houver procedido de má-fé, será obrigado a indenizar o evicto nos termos sobreditos, com esta diferença: $\S 1^{\circ} \mathrm{Se} o$ valor da cousa, ao tempo da eviç̧ão, for superior ao valor prestado, responderá o alheador por essa diferença. $\S 2^{\circ}$ Será responsável o alheador por todas as perdas e danos que resultarem da eviç̧ão, não excetuando sequer as despesas voluptuárias."

95 Cf. LIMA, Fernando Andrade Pires de; e VARELA, João de Matos Antunes. op. cit. p. 184.

96 A possibilidade de ocorrência da evicção é expressamente reconhecida pelo art. $903^{\circ}$.

97 BIANCA, Cesare Massimo. La vendita e la permuta cit. p. 777, afirma que "il fatto evizionale inteso come evento lesivo non proppone rimedi distinti rispetto a quelli spettanti al compratore per il mancato o carente acquisto del diritto"

98 Para LIMA, Fernando Andrade Pires de; e VARELA, João de Matos Antunes. op. cit. v. 2. p. 185-6 e 191-2, essas disposições aplicam-se tanto aos casos em que o comprador está de boa-fé e o vendedor age com dolo, quanto aos casos, mais raros, em que o vendedor está de boa-fé e o comprador age com dolo. 
da Silva Pereira, por exemplo, afirma que como a garantia pela evicção "não [se] funda na culpa do alienante, vinga a responsabilidade deste, ainda que de boa-fé" 99 Devemos, portanto, examinar as noções de dolo e culpa e em seguida verificar se o que deve ser averiguado quando ao aumento de responsabilidade do alienante é realmente a sua má-fé - como dizem Sílvio Rodrigues, ${ }^{100}$ a doutrina francesa e belga, ${ }^{101}$ o Código Civil argentino e o Código Civil português de 1967 - ou se na realidade devemos atentar para o dolo ou culpa.

A culpabilidade em sentido amplo, que abrange a culpa em sentido restrito e o dolo, diz respeito ao fato de alguém agir de forma reprovável ou censurável pelo direito. Isso significa que objetivamente pode-se concluir que o agente poderia e deveria ter agido de maneira diversa. O dolo pode ser direto ou eventual (também chamado de necessário). Os casos de dolo direto são "aqueles em que o agente representa ou prefigura no seu espírito determinado efeito de sua conduta e quer esse efeito como fim de sua atuação, apesar de conhecer a ilicitude dele". Já o dolo eventual é aquele no qual o agente não quer diretamente o ato ilícito, mas "o previu como uma consequência necessária, segura, da sua conduta" Em outras palavras, não é necessária a intenção de causar um dano, mas a consciência do prejuízo e do caráter danoso do ato - é o chamado elemento intelectual do dolo. ${ }^{102}$

A culpa, em contrapartida, pode ser consciente ou inconsciente, conforme o agente conceba ou não a possibilidade do fato vir a se verificar. Além disso, a culpa deve ser avaliada conforme a diligência de um bonus paterfamilias, segundo o padrão de cuidado do homem médio e normal - culpa in abstracto - e não segundo o padrão de cuidado do próprio causador do dano na condução habitual dos seus negócios - culpa in concrecto. Ademais, deve-se perguntar se no âmbito da culpa entraria somente a mera negligência, entendida enquanto falta de cuidado ou zelo, ou se deve ser computada a falta de perícia ou aptidão. ${ }^{103}$ Ressalte-se que o Código Civil brasileiro, no art. 186, fala apenas

99 Cf. PEREIRA, Caio Mário da Silva. op. cit. v. 3. p. 139.

100 Cf. RODRIGUES, Sílvio. op. cit. v. 3. p. 119-21.

101 Apesar de afirmarem que a responsabilidade pela evicção é independente da posição subjetiva do alienante, os doutrinadores franceses, ao referirem-se às considerações de ordem subjetiva, falam em boa-fé e má-fé, não se referindo a culpa ou dolo. MAZEAUD, Henri et al. op. cit. p. 234. PLANIOL, Marcel; RIPERT, Georges. op. cit. p. 122, afirmam que "peu importe la bonne ou la mauvaise foi du vendeur, et c'est la une solution très rigoureuse: elle constitue une dérogation très nette au régime de droit commun des contrats" No mesmo sentido, DE PAGE, Henri. op. cit. t. 4. p. 170, afirma que "la bonne ou la mauvaise foi du vendeur sont sans influence sur la garantie d'eviction", e completa: "les dommage-intérêts sont toujour dus même si le vendeur est de bonne foi"

102 Cf. VARELA, João de Matos Antunes. op. cit. p. 562-3, p. 570 e 572.

103 BIANCA, Cesare Massimo. Diritto civile: la responsabilità. Milano: Giuffrè, 1994. v. 5. p. 578-9, diferencia bem a negligência, imprudência e imperícia. Segundo ele, "l'incuria o negligenza in senso stretto consiste nel difetto dell'attenzione volta alla salvaguardia altrul" e "l'imprudenza consiste nel difetto delle misure di cautele idonee a prevenire il danno". Por fim, "l'imperizia è l'inosservanza delle regole tecniche proprie 
em negligência e imprudência. Já o Código Penal brasileiro, em seu art. 18, II, inclui a hipótese de imperícia. Entende-se que a imperícia também deve ser considerada, pois não seria justo que prejudicasse a pessoa com quem o agente se relaciona, além de ser a solução mais pedagógica do ponto de vista social. Assim, a solução melhor é um padrão objetivo e abstrato também quanto aos conhecimentos e capacidade exigíveis do agente. ${ }^{104}$

Analisadas as noções de culpa e dolo, verifica-se que a doutrina italiana diferencia esses conceitos da noção de má-fé no tocante à alienação de bem alheio e à evicção. Nem todo alienante de boa-fé - que ignora ser a coisa alheia - está necessariamente isento de culpa. O mais usual é que esteja. Porém, a culpa do alienante pode consistir justamente no fato de que negligentemente ignorasse a verdadeira titularidade do bem. Por outro lado, apesar de sempre agir dolosamente o alienante que sabe ser a coisa alheia e não comunica o fato ao adquirente, é possível vislumbrar uma hipótese de má-fé em que pode não haver sequer culpa. Diz D. Rubino que o alienante pode ter tomado todas as precauções, procurado com todas as suas forças adquirir o direito do terceiro, ou ter sido inclusive ludibriado por este, por exemplo, com uma promessa de venda não adimplida. ${ }^{105}$

No direito italiano, a consequência da alienação de coisa alheia e da evicção varia conforme haja ou não culpa do alienante em relação à ignorância sobre a verdadeira titularidade da coisa. Não se trata de uma mera oposição entre boa-fé e má-fé do alienante, como dão a entender as outras legislações examinadas, mas da existência ou ausência de culpa em sentido amplo em relação à própria boa-fé ou má-fé. Disso resulta que o alienante de boa-fé, mas com culpa, sofrerá as mesmas consequências do alienante que estava de má-fé e dolosamente vendeu o bem ao adquirente. ${ }^{106}$

$\mathrm{Na}$ Itália, portanto, se não houver culpa nem dolo do alienante, este não responde pelo aumento de valor da coisa entre o momento da aquisição e da evicção. Não se deve ressarcir toda a perda e dano, mas somente o chamado "interesse negativo", que consiste em colocar o adquirente em uma "condição economicamente equivalente àquela na qual se encontraria se não tivesse celebrado o contrato" Se houver culpa ou dolo do alienante, aplica-se a solução genérica da responsabilidade pelo inadimplemento obrigacional. Nesse caso, por força do art. 1.223 , para o qual o art. $1.479,2^{\circ}$ co., faz remissão expressa, o alienante responde pelo chamado "interesse positivo", que consiste nos danos emergentes e lucros cessantes. Se a coisa estiver valorizada, é justamente

di una determinata professione"

104 Cf. VARELA, João de Matos Antunes. op. cit. p. 573-5 e p. 578-81.

105 Para RUBINO, Domenico. op. cit. p. 369-70, "non sempre vi è dolo ogni qualvolta vi è mala fede, intesa come conoscenza dell'alienità del diritto: non, ad es., se il venditore aveva preventivamente preso tutte le precauzioni per mettersi in grado di procurare al compratore l'acquisto, ottenendo dal terzo proprietario una promessa di vendita, rimasta poi inadempiuta per colpa del terzo; in un caso del genere, anzi, sembrerebbe da escludere anche la colpa"

106 Cf. RUBINO, Domenico. op. cit. p. 362-4 e 713. 
nestes que entra a diferença entre o preço pago e o valor da coisa à época da evicção. Segundo A. De Martini, à responsabilidade pela evicção já existente no caso de ausência de culpa, "deve agganciarsi" no caso de culpa ou dolo, também a responsabilidade pelo inadimplemento. ${ }^{107}$

De todo modo, por mais interessantes que sejam todas essas soluções estrangeiras, essa diferenciação de responsabilidade de ordem subjetiva sempre decorre de uma previsão legislativa expressa. Como vimos, nos sistema francês e belga, não há previsão e a doutrina entende não ser possível a responsabilização diferenciada do alienante. ${ }^{108}$ Assim, não obstante a respeitável opinião de Sílvio Rodrigues, ${ }^{109}$ portanto, devemos acatar a corrente majoritária segundo a qual, no Brasil, a indenização devida pelo alienante ao evicto não é atenuada se aquele estiver de boa-fé ou sem culpa.

\section{Segue. Desvalorização e deterioração}

Vista a questão da valorização da coisa sob a égide de Código Civil de 1916, devemos nos perguntar acerca do problema inverso, da desvalorização do bem evicto. Como o art. 1.109 do Código determinava a restituição total do preço pago, o que aconteceria se a coisa estivesse desvalorizada ao momento da evicção? Teria o evicto direito realmente ao valor que pagara, ou ao valor da coisa na época da evicção? A doutrina, de um modo geral, simplesmente entendia que se a coisa estivesse desvalorizada, ainda assim o evicto teria direito à integralidade do preço pago, mas não fazia nenhuma consideração ulterior. ${ }^{110}$ Nossa tese, todavia, é de que os dispositivos referentes à deterioração da coisa aplicam-se a qualquer caso de diminuição de valor do bem, independentemente de degradação física. Consequência disso é que em qualquer caso de desvalorização, se o adquirente tiver agido com dolo, ou tiver auferido vantagens das diminuições de valor, não terá direito à integralidade do preço pago. Essa perspectiva, aliás, coaduna-se com a doutrina que entende ser aplicável a disciplina da evicção também aos bens incorpóreos, que, obviamente, não se podem degradar fisicamente. ${ }^{\prime \prime \prime}$

107 Cf. BIANCA, Cesare Massimo. La vendita e la permuta. cit. p. 683-4, 686, nt. 1, e 778; RUBINO, Domenico. op. cit. p. 367, 369 e 711-2; e DE MARTINI, Angelo. op. cit. p. 1067. Segundo RUBINO, Domenico. op. cit. p. 707, "se non vi è colpa, la garanzia risarcisce solo l'interesse negativo, cioè mira solo a porre il compratore in una condizione economicamente equivalente a quella in cui si sarebbe trovato se non avesse stipulato il contratto"

108 Cf. MAZEAUD, Henri et al. op. cit. p. 234; PLANIOL, Marcel; RIPERT, Georges. op. cit. p. 122; e DE PAGE, Henri. op. cit. t. 4. p. 170.

109 Cf. RODRIGUES, Sílvio. op. cit. v. 3. p. 119-21.

110 Cf. DALLAGNOLO, Dorval Baptista. op. cit. p. 84; LEMOS, Patricia Faga Iglecias. op. cit. p. 237.

111 Para COSTA, José Eduardo da. Evicção nos contratos onerosos: fundamento, natureza e estrutura. São Paulo: Saraiva, 2004. p. 19-2, a responsabilidade pela evicção abrange um campo bastante amplo. Deve-se compreender a palavra "coisa" utilizada pelo Código numa acepção abrangente, englobando desde posse, direito de propriedade e direitos reais sobre bens corpóreos até direitos reais sobre bens incorpóreos e 
Uma correta análise do problema da desvalorização deve ser realizada em conjunto com o exame dos dispositivos específicos do Código Civil que dizem respeito à deterioração da coisa evicta. Trata-se dos arts. 1.110 e 1.111 do Código Civil de 1916, que foram repetidos sem alteração no Código Civil de 2002 (arts. 451 e 452). Dispunha o art. 1.110 que subsistia para o alienante a obrigação prevista no art. 1.109 ainda que a coisa alienada estivesse deteriorada, exceto havendo dolo do adquirente. Cabe relembrar que 0 art. 1.109 e seus incisos diziam respeito à restituição do preço e às indenizações pelos frutos, despesas judiciais e com o contrato, e prejuízos diretamente resultantes da evicção. Já o art. 1.111 estabelecia que, se o adquirente tivesse auferido vantagens das deteriorações, o valor seria deduzido da quantia que o alienante lhe tivesse que dar, salvo se não tivesse sido condenado a indenizar o terceiro. É a solução, aliás, do direito francês, ${ }^{112}$ italiano, ${ }^{113}$ argentino ${ }^{114}$ e português. ${ }^{115}$

Em síntese, esses dispositivos previam que a restituição do preço só não seria integral em duas situações - se a deterioração da coisa proviesse de dolo do adquirente ou se este tivesse auferido vantagens das deteriorações e não tivesse sido condenado a indenizá-las ao evictor. As verbas serão devidas integralmente ao evicto mesmo se a coisa estiver deteriorada ou depreciada, quer em virtude de caso fortuito ou força maior, quer em virtude de negligência do adquirente. Somente em caso de deterioração dolosa é que

direitos pessoais. MIRANDA, Francisco Cavalcanti Pontes de. op. cit. p. 236, esclarece que pode haver responsabilidade pela eviç̧ão em todo contrato oneroso - e excepcionalmente em outros negócios jurídicos - que tenham um objeto suscetível de vício jurídico. Vício jurídico é o vício de haver sobre esse objeto ou se poder exercer sobre ele posição jurídica - direito, pretensão, ação ou exceção - de um terceiro.

$112 \mathrm{O}$ art. 1632 do Código Civil francês determina: "Mais si l'acquéreur a tiré profit des dégradations par lui faites, le vendeur a droit de retenir sur le prix une somme égale à ce profit" Cf. JOSSERAND, Louis. op. cit. t. 2. p. 581-2. Para SAVATIER, op. cit. t. 2. p. 336, "s'il a tiré un enrichissement des détériorations apportées par lui á la chose, cet enrichissement viendra en diminution du prix. Ainsi, lorsqu'il a démoli la maison achetée pour en vendre le matériaux, il déduira leur valeur du prix d'achat de la maison"

$113 \mathrm{O}$ art. $1479,2^{\circ}$ co., última parte do Código Civil italiano determina: "Se la diminuzione di valore o il deterioramento derivano da un fatto del compratore, dall'ammontare suddetto si deve detrarre l'utile che il compratore ne ha ricavato" Com relação ao direito italiano, afirma BIANCA, Cesare Massimo. Vendita (diritto vigente). In: Novissimo digesto italiano. Torino: UTET, 1975. v. 20. p. 625, que: "Eventuali diminuzioni di valori della cosa o eventuali deterioramenti non danno luogo, di regola, a pretese risarcitorie. Se tuttavia, derivano dal fatto del compratore e questi ne ha ricavato un utile, tale utile è detratto dall'ammontare dell'obbligo di risarcimento o di indennizzo del venditore".

114 Por fim, com relação ao direito argentino, o Código Civil dispõe em seu art. 2124: "El vendedor tiene derecho a retener de lo que debe pagar, la suma que el comprador hubiere recibido del que lo ha vencido, por mejoras hechas por el vendedor antes de la venta, y la que hubiere obtenido por las destrucciones en la cosa comprada" WAYAR, Ernesto. op. cit. p. 10, justifica esse sistema diferenciado, ao afirmar que, no caso "el comprador si beneficia economicamente destroyendo la cosa, por lo qual el vendedor está autorizado a deducir esse beneficio de la suma que debe devolver". É diferente da hipótese de deterioração na qual o adquirente não auferiu vantagens. Neste caso, "el comprador no obtiene ningún beneficio de la destrucción da la cosa, por lo qual el vendedor no está autorizado a efectuar deducciones".

$115 \mathrm{O} \mathrm{n}^{\circ} 2$ do art. $894^{\circ}$ do Código Civil português de 1966 prevê que "se o comprador houver tirado proveito da perda ou diminuição de valor dos bens, será o proveito abatido no montante do preço e da indenização que o vendedor tenha de pagar-Ihe" 
a integralidade das verbas não é devida. A integralidade da indenização mesmo no caso de negligência é justificável, pois como o adquirente acreditava que a coisa fosse sua, não tinha dever de velar pela sua boa conservação. ${ }^{116}$

É interessante destacar que o art. 215 do Código Comercial, hoje não mais em vigência, tinha a seguinte redação: "a restituição do preço tem lugar, posto que a coisa vendida se ache depreciada na quantidade ou na qualidade ao tempo da evicção por culpa do comprador ou força maior. Se, porém, o comprador auferir proveito da depreciação por ele causada, o vendedor tem direito para reter a parte do preço que for estimada por arbitradores". Não obstante a menção à estimação por arbitradores, e a ausência da previsão de que não seriam quaisquer vantagens auferidas da deterioração que permitiriam a diminuição das verbas devidas ao evicto, mas apenas aquelas que não tivessem sido indenizadas ao evictor, entende-se que o conteúdo do Código Comercial é substancialmente o mesmo do Código Civil. ${ }^{117}$ Todavia, o uso da palavra "depreciação" ao invés de "deterioração" pelo diploma mercantil, talvez possa nos indicar uma referência a qualquer diminuição de valor que a coisa tenha sofrido, independentemente de deterioração física.

Quanto ao conceito de deterioração, F. C. Pontes de Miranda a define como "qualquer alteração que diminua o valor" da coisa. ${ }^{118} \mathrm{O}$ problema é que a palavra parece ter uma forte carga de materialidade. Caio Mário da Silva Pereira dá como exemplo de deterioração a demolição de um prédio; Luiz da Cunha Gonçalves fala em um pinhal, no qual a maior parte dos pinheiros foi cortada. ${ }^{119} \mathrm{D}$. Rubino é categórico no sentido de que "il deterioramento è quello materiale" ${ }^{120}$ Ao lado do conceito de deterioração, aliás, temos que incluir o de perecimento. Apesar dos arts. 1.110 e 1.111 (e arts. 451 e 452 do Código Civil atual) não o mencionarem, para D. Rubino, "tutto quanto detto finora per il semplice deterioramento vale, mutatis mutandis, anche per il perimento, totale o parziale, della cosa" ${ }^{121}$ À hipótese de perecimento total ou parcial da coisa são aplicáveis

116 Cf. SANTOS, João Manuel de Carvalho. op. cit. p. 394.

117 Cf. MIRANDA, Francisco Cavalcanti Pontes de. op. cit. p. 327-9. O autor, p. 329, esclarece que: "Na interpretação das duas regras jurídicas, devemos entender que o conteúdo é o mesmo: O Código Comercial, art. $215,2^{\mathrm{a}}$ alínea, $1^{\mathrm{a}}$ parte, falou de 'por culpa do comprador ou força maior'; o Código Civil, de 'exceto havendo dolo do adquirente'. A contrario sensu, foi o que estabeleceu o Código Comercial: 'por culpa' = 'exceto havendo dolo do adquirente" "

118 Cf. MIRANDA, Francisco Cavalcanti Pontes de. op. cit. p. 327.

119 Respectivamente, PEREIRA, Caio Mário da Silva. op. cit. v. 3. p. 140-1; e GONÇALVES, Luiz da Cunha. Tratado de direito civil cit. v. 6. t. 1. p. 42.

120 Cf. RUBINO, Domenico. op. cit. p. 364. A doutrina italiana, aliás, na classificação dos bens, ao lado dos bens consumíveis e inconsumíveis, costuma elencar os bens deterioráveis e não-deterioráveis, cf. GAZZONI, Francesco. Manuale di diritto privato. 5. ed. Napoli: ESI, 1994. p. 190-1.

121 Cf. RUBINO, Domenico. op. cit. p. 716. 
os mesmos princípios, uma vez que a diferença entre deterioração e perecimento é apenas de caráter quantitativo, e não qualitativo. ${ }^{122}$

Já quanto à diminuição de valor, como hipótese distinta da deterioração, entende-se que compreende os casos em que o estado físico da coisa permanece inalterado. ${ }^{123}$ Todavia, não é porque há essa diferença conceitual entre deterioração e desvalorização, que não se deva entender aplicáveis a qualquer hipótese de desvalorização da coisa os arts. 1.110 e 1.111 do Código Civil de 1916. É a posição de F. C. Pontes de Miranda, que dizia: "a minusvalia não se leva em conta, salvo se proveio de dolo do outorgado ou se da desvalorização ele auferiu, vantagem" Ressaltava ainda que se aplicavam as únicas regras jurídicas existentes no Código sobre subtraibilidade por desvalorização - os arts. $1.110 \mathrm{e}$ 1.111 -, pois, dessa forma, "ao preço se subtraem as vantagens ou a desvalia oriunda de dolo" 124

Esse posicionamento, aliás, encontra respaldo nas legislações estrangeiras examinadas, as quais, na maioria das vezes, estabelecem expressamente as mesmas consequências jurídicas das deteriorações para as hipóteses de perecimento e desvalorização do bem.

O Código Civil português de 1966 prevê no $\mathrm{n}^{\circ} 1$ do art. $894^{\circ}$ que o comprador "tem o direito de exigir a restituição integral do preço, ainda que os bens se hajam perdido, estejam deteriorados ou tenham diminuído de valor por qualquer outra causa" O art. 1631 Código Civil francês determina: "Lorsqu'à l'époque de l'éviction, la chose vendue se trouve diminuée de valeur, ou considérablement détériorée, soit par la négligence de l'acheteur, soit par des accidents de force majeure, le vendeur n'en est pas moins tenu de restituer la totalité du prix" ${ }^{125} \mathrm{O}$ art. 2.118 do Código Civil argentino estabelece que "verificada la evicción, el vendedor debe restituir al comprador el precio recibido por él, sin intereses, aunque la cosa haya disminuido de valor, sufrido deterioros o pérdidas en parte, por caso fortuito o por culpa del comprador" ${ }^{126}$ Por fim, o art. 1.479,

122 Cf. MIRANDA, Francisco Cavalcanti Pontes de. op. cit. p. 330; e VILLELA, João Baptista. op. cit. p. 24-5.

123 RUBINO, Domenico. op. cit. p. 364, afirma que: "La diminuzione di valore, come ipotesi distinta dal deterioramento, comprende i casi in cui, pur rimanendo inalterato lo stato fisico della cosa, sia cambiata la valutazione corrente, di mercato, di essa".

124 Cf. MIRANDA, Francisco Cavalcanti Pontes de. op. cit. p. 316-7. Também ALVES, João Luiz. Código Civil da República dos Estados Unidos do Brasil anotado. 3. ed. atual. por Erbert Chamoun. Rio de Janeiro: Borsoi, 1958. v. 4. p. 208, apesar de não admitir expressamente, parecia aludir a uma aplicação mais ampla dos dispositivos referentes à deterioração, pois comentava os artigos do Código Civil utilizando a palavra "desvalorização"

125 PLANIOL, Marcel; RIPERT, Georges. op. cit. p. 120-1; e MAZEAUD, Henri et al. op. cit. p. 234-5 corroboram a letra da lei, afirmando que o vendedor terá de restituir a integralidade do preço mesmo se a diminuição de valor da coisa ou deterioração decorreu de negligência do comprador. JOSSERAND, op. cit. t. 2. p. 581-2, todavia, critica essa disciplina e a atribui a uma errônea interpretação de fragmentos do Digesto realizada por Dumoulin e Pothier. Não é nosso objetivo, todavia, aprofundar esse aspecto.

126 Aponta LORENZETTI, Ricardo Luis. op. cit. p. 285, que "no rige la correspectividad de las prestaciones 
$2^{\circ}$ co., primeira parte, do Código Civil italiano de 1942 estabelece que: "Il venditore è tenuto a restituire all'acquirente il prezzo pagato, anche se la cosa è diminuita di valore $o$ è deteriorata $[\ldots] .{ }^{127}$

Em síntese, de todo o exposto, nossa conclusão é que os arts. 1.110 e 1.111 do Código Civil de 1916 deviam ser interpretados ampliativamente, para abranger não somente os casos de deterioração material, mas de perecimento e diminuição de valor do bem. Assim, a restituição do preço só não seria integral nos termos do art. 1.109 em caso de dolo do adquirente e deste ter auferido vantagens das deteriorações.

Por fim, devemos apontar o aspecto que talvez seja o mais relevante nos dias de hoje. Todo o sistema que expusemos fazia sentido face ao Código Civil antigo. Por isso, aliás, até agora nos referimos principalmente ao Código Civil de 1916 e evitamos ao máximo fazer referência aos arts. 451 e 452 do novo Código Civil. Ocorre que a repetição na lei atual do disposto nos arts. 1.110 e 1.111 gerou uma séria incompatibilidade de ordem lógica. $\mathrm{O}$ art. 450, parágrafo único, prevê que a restituição do preço far-se-á com base no valor da coisa à época da eviç̧ão. Em seguida, o art. 451 estabelece que "subsiste para o alienante esta obrigação [qual seja, de restituir o preço e indenizar conforme os incisos do art. 450] ainda que a coisa alienada esteja deteriorada, exceto havendo dolo do adquirente"

Isso fazia sentido quando a restituição do preço era integral e a coisa deteriorada encontrava-se diminuída de valor em relação ao momento da alienação. Mesmo assim, se não houvesse dolo, a indenização far-se-ia com base nesse valor maior. Como a restituição agora é do preço correspondente ao valor da época da eviç̧ão, o disposto no art. 451 é inócuo, uma vez que a obrigação que "subsiste para o alienante" consiste no valor da coisa já deteriorada. Em outras palavras, o disposto no art. 450 já computa os casos de deterioração. Ao determinar que a indenização far-se-á com base no valor atual, já é deduzido automaticamente o valor das deteriorações.

Portanto, não faz sentido a exceção para o caso de dolo. Ao lermos o art. 451 , inclusive, não é possível entender qual o valor a ser pago nesse caso. Pode-se chegar ao absurdo de se interpretar o dispositivo no sentido de não "subsistir" indenização alguma para o caso de deterioração dolosa por parte do adquirente, ou deste ter auferido vantagens, o que certamente significaria penalizá-lo excessivamente.

que permitiria disminuir el precio si ha disminuido el valor de la cosa"

127 Para doutrina italiana, cf. BIANCA, Cesare Massimo. La vendita e la permuta cit. p. 686. DE MARTINI, Angelo. op. cit. p. 1065-6, diz: "La restituzione del prezzo deve essere integrale, anche se la cosa sia diminuita di valore o deteriorata, ed anche se tale diminuzione di valore o tale deterioramento dipendano da fatto del compratore. Il quale potrà risponderne ad altro titolo, ma non attraverso una attenuazione di questa conseguenza restitutoria, che deve essere integrale" 
Nossa conclusão é que a manutenção dos arts. 451 e 452 no Código Civil não faz sentido, pois, ao se determinar a restituição do preço com base no valor posterior da coisa, igualou-se, para todos os casos, a hipótese prevista apenas para o caso de dolo no Código Civil de 1916, qual seja, a não-restituição integral do preço. Tanto é assim, que o Código Civil espanhol, que prevê no art. $1478,1^{\circ}$, a restituição do preço que a coisa tiver ao tempo da evicção, seja ele maior seja ele menor que o da venda, não contém nenhum dispositivo equivalente aos arts. 451 e 452 do nosso Código Civil. Esses dispositivos para os casos de deterioração, perecimento e diminuição de valor da coisa só fazem sentido quando o regime adotado pela legislação é o da restituição integral do preço, como ocorre, aliás, nos Códigos Civis portugueses, antigo e atual, francês, argentino e italiano.

\section{Conclusão}

De tudo que foi exposto, vimos que responsabilidade pela evicção costuma ser tratada pelos Códigos Civis modernos separadamente em relação ao inadimplemento obrigacional. Sendo assim, e tendo em vista que o alienante responde pela evicção independentemente de culpa, as legislações costumam consagrar um sistema de indenização diferente daquele estabelecido para o inadimplemento. Em regra, o alienante não tem que indenizar toda a perda e dano, mas seu dever se resume à restituição do preço pago e à indenização de algumas verbas especificadas pela lei.

Nosso objetivo neste artigo foi tratar da restituição do preço, tendo em vista a inclusão do parágrafo único do art. 450, que, mudando a sistemática do Código Civil de 1916, determinou que a restituição fosse do preço correspondente ao valor da coisa na época da evicção, e não mais do preço que fora pago. A justificativa da doutrina e jurisprudência é que, no regime anterior, ficaria desprotegido o evicto caso a coisa estivesse valorizada, pois receberia de volta apenas o preço que pagara. A alteração legislativa, todavia, acabou também sendo criticada, pois teria criado o problema inverso. No regime atual, se a coisa estivesse desvalorizada, o evicto também ficaria desprotegido, pois receberia menos do que pagou.

Na realidade, vemos que grande parte do problema da valorização da coisa colocado pela doutrina sob a égide do velho Código decorria de uma premissa errada. Confundia-se a valorização da coisa em si, com uma valorização decorrente de fenômenos puramente monetários, como a perda de valor da moeda em decorrência da inflação. Como vimos, apesar da adoção do princípio do nominalismo, a correção monetária estava e está consagrada no nosso ordenamento jurídico. Portanto, não é correta a afirmação de determinados autores, sob a égide do Código antigo, de que haveria sempre a valorização da coisa decorrente da inflação e, logo, a solução do Código antigo seria injusta, pois deixaria o adquirente sempre desprotegido. 
Aliás, também quanto ao problema da injustiça que supostamente sofreria o adquirente no caso da coisa estar valorizada - Código antigo - ou desvalorizada Código novo, podemos tecer algumas considerações críticas a essa busca a qualquer custo pela satisfação dos interesses do evicto. Ao se buscar proteger sempre o evicto, muitas vezes se esquece do fato de que a responsabilidade pela evicção não depende de culpa do alienante. Nossa legislação, como a francesa, não permite essa diferenciação no regime de indenização entre o alienante com culpa e o alienante sem culpa. Outros Códigos Civis, trazem uma solução muito mais adequada, uma vez que trazem uma responsabilidade atenuada conforme o alienante esteja de boa-fé (Código Civil português antigo e Código Civil argentino) ou, utilizando um termo mais adequado segundo a doutrina italiana, ausente de culpa.

Por fim, quanto ao problema da desvalorização da coisa, primeiramente, sob o Código antigo, chamamos atenção para os dispositivos referentes à deterioração. Entendemos, com base em doutrina e legislação estrangeira, que apesar de não explicitado pela lei, os artigos têm aplicação também aos casos de perecimento e de desvalorização do bem por qualquer motivo, mesmo que não tenha havido qualquer tipo de degradação material da coisa. Além disso, sob o Código novo, a manutenção desses dispositivos conjugada ao novo critério de aferição do preço a ser restituído acaba dando ensejo a uma disciplina sistematicamente confusa, de difícil compreensão.

Com base em todo o exposto, concluímos que a alteração do regime da restituição do preço trouxe mais incômodos que benefícios. A maior parte dos Códigos Civis analisados consagra o regime da restituição do preço pago, como fazia o nosso Código Civil de 1916. Além disso, o problema da valorização da coisa já havia sido resolvido no Brasil pela doutrina, que entendia ser esse aumento de valor um prejuízo diretamente resultante da evicção, e portanto, indenizável ao evicto com base no art. 1.109, inciso II, do Código velho. Como esclarece o Parecer Vicente Arruda, além disso, a proposta de alteração do parágrafo único do art. 450 traz uma solução ainda pior. Era melhor a redação do Código Civil de 1916. Todavia, a solução ideal seria consagrar, como faz o Código Civil italiano, um sistema diferenciado de indenização, conforme o alienante tenha ou não culpa lato sensu na alienação do bem alheio, pois dessa forma não se oneraria tanto o alienante sem culpa em prol dos interesses do evicto.

São Paulo, fevereiro de 2011.

Referências

ALVES, João Luiz. Código Civil da República dos Estados Unidos do Brasil anotado. 3. ed. atual. por Erbert Chamoun. Rio de Janeiro: Borsoi, 1958. v. 4. 
ALVES, Jones Figueirêdo. In: FIÚZA, Ricardo. Novo Código Civil comentado. 2. ed. São Paulo: Saraiva, 2003.

AMARAL, Francisco. Direito civil: introdução. 6. ed. Rio de Janeiro: Renovar, 2006.

ANTUNES VARELA, João de Matos. Das obrigações em geral. 10. ed. Coimbra: Almedina, 2000. v. 1.

ASCARELLI, Tullio. Obbligazioni pecuniarie: art. 1277-1284. In: SCIALOJA, Antonio; BRANCA, Giuseppe. Commentario del Codice Civile: libro quarto - delle obbligazioni. Bologna: Foro Italiano, 1959.

. Studi giuridici sulla moneta. Milano: Giuffrè, 1952.

BARBA, Angelo. Spese (diritto privato). In: Enciclopedia del diritto. Milano: Giuffrè, 1990. v. 43.

BEVILÁQUA, Clóvis. Código civil dos Estados Unidos do Brasil comentado. 6. ed. Rio de Janeiro: Francisco Alves, 1946. v. 4.

BIANCA, Cesare Massimo. Diritto civile: l'obbligazione. Milano: Giuffrè, 1993. v. 4.

. Diritto civile: la responsabilità. Milano: Giuffrè, 1994. v. 5.

. La vendita e la permuta. In: VASSALLI, Filippo (Org.). Trattato di diritto civile italiano.

Torino: UTET, 1972. v. 7. t. 1.

Vendita (diritto vigente). In: Novissimo digesto italiano. Torino: UTET, 1975. v. 20.

CHIANALE, Angelo. Evizione. In: Digesto delle discipline privatistiche: sezione civile. Torino: UTET, 1998. v. 8.

COMPARATO, Fábio Konder. Obrigações de meio, de resultado e de garantia. In: ENSAIOS e pareceres de direito empresarial. Rio de Janeiro: Forense, 1978.

COSTA, José Eduardo da. Evicção nos contratos onerosos: fundamento, natureza e estrutura. São Paulo: Saraiva, 2004.

Tratado de direito civil: em comentário ao Código Civil português. 2. ed. [1. ed. bras.] São Paulo: Max Limonad, 1957. v. 6. t. 1

DALlaGNOlO, Dorval Baptista. Da eviç̧ão na compra e venda imobiliária. 1993. Tese (Doutorado) - Faculdade de Direito, Universidade de São Paulo, São Paulo.

DE MARTINI, Angelo. Evizione (diritto civile). In: Novissimo digesto italiano. Torino: UTET, 1957. v. 6.

DELOGU, Lucia. La vendita. In: VISINTINI, Giovanna (Org.). Trattato della responsabilità contrattuale. Padova: CEDAM, 2009. v. 2.

DE PAGE, Henri. Traité élémentaire du droit civil belge: principes - doctrine - jurisprudence. Les principaux contrats usuels (prèmiere partie). 2. ed. Bruxelles: Émile Bruylant, 1943. t. 4. 
DI MAJO, Adolfo. Obbligazioni pecuniarie. In: Enciclopedia del diritto. Milano: Giuffrè, 1979. v. 29.

. Responsabilità contrattuale. In: DIGESTO delle discipline privatistiche: sezione civile. Torino: UTET, 1998. v. 17.

ENNECCERUS, Ludwig. Derecho de obligaciones. In: ENNECCERUS, Ludwig; KIPP, Theodor; WOLFF, Martin. Tratado de derecho civil. Trad. esp. por Blás Péres Gonzáles e José Alguer. Barcelona: Bosch, 1935. v. 2.

GALGANO, Francesco. Vendita (diritto privato). In: Enciclopedia del diritto. Milano: Giuffrè, 1993. v. 46.

GAZZONI, Francesco. Manuale di diritto privato. 5. ed. Napoli: ESI, 1994.

GHESTTN, Jacques; BILLIAU, Marc. Le prix dans les contrats de longue durée. Paris: LGDJ, 1990. GOMES, Orlando. Contratos. 26. ed. atual. por Antonio Junqueira de Azevedo e Francisco Paulo De Crescenzo Marino. Rio de Janeiro: Forense, 2007.

. Obrigações. 16. ed. atual. por Edvaldo Brito. Rio de Janeiro: Forense, 2005.

GONÇALVES, Luiz da Cunha. Da compra e venda no direito comercial brasileiro. 2. ed. São Paulo: Max Limonad, 1950.

GONDIM, Regina Bottentuit. Da evicção. 1955. Tese (Cátedra) - Faculdade de Direito de Niterói, Niterói.

GUIDA, Giovanni. et. al. Le obbligazioni pecuniarie. In: PATTI, Salvatore; e VACCA, Letizia. Trattato delle obbligazioni: le figure speciali. Padova: CEDAM, 2010. v. 5.

INZITARI, Bruno. Il principio nominalistico. In: INZITARI, Bruno; VISENTINI, Gustavo; e DI AMATO, Astolfo. Moneta e valuta. In: GALGANO, Francesco. Trattato di diritto commerciale e di diritto pubblico dell'economia. Padova: CEDAM, 1983, v. 6.

Miglioramenti (diritto privato). In: Enciclopedia del diritto. Milano: Giuffrè, 1976. v. 26.

JOSSERAND, Louis. Cours de droit civil positif français: Théorie générale des obligations. Les principaux contrats du droit civil. Les suretés. 2. ed. Paris: Sirey, 1933. t. 2.

LANZANA, Antonio Evaristo Teixeira. Economia brasileira: fundamentos e atualidade. 2. ed. São Paulo: Atlas, 2002.

LARENZ, Karl. Derecho de obligaciones. Trad esp. por Jaime Santos Briz. Madrid: Revista de Derecho Privado, 1959. t. 2.

LEMOS, Patrícia Faga Iglecias. O instituto da evicção à luz do Código Civil brasileiro e do projeto de Código Civil (634-B/75). Revista do Instituto de Pesquisa e Estudos, Bauru. n. 24. dez./mar. 1998-1999. 
LIMA, Fernando Andrade Pires de; e VARELA, João de Matos Antunes. Código civil anotado: artigos $762^{\circ}$ a $1250^{\circ}$ 4. ed. Coimbra: Coimbra, 1997. v. 2.

LÔBO, Paulo Luiz Netto. In: AZEVEDO, Antonio Junqueira de (Coord.). Comentários ao Código Civil: parte especial: das várias espécies de contratos (arts. 481 a 564). São Paulo: Saraiva, 2003. v. 6 .

LORENZETTI, Ricardo Luis. Tratado de los contratos. Buenos Aires: Rubinzal-Culzoni, 1999. t. 1.

LUMINOSO, Angelo. Vendita. In: Digesto delle discipline privatistiche: sezione civile. Torino: UTET, 1999. v. 19.

MARTINS-COSTA, Judith. A boa-fé no direito privado: sistema e tópica no processo obrigacional. São Paulo: RT, 1999.

. Os avatares do abuso de direito e o rumo indicado pela boa-fé. In: DELGADO, Mário Luiz; ALVES, Jones Figueirêdo. Novo Código Civil: questões controvertidas: parte geral do Código Civil. São Paulo: Método, 2007. v. 6.

MAZEAUD, Henri; MAZEAUD, Léon; MAZEAUD, Jean. Leçons de droit civil: principaux contrats. 4. ed. par Michel de Juglart. Paris: Montchrestien, 1974. t. 3, v. 2.

MENEZES CORDEIRO, António. Tratado de direito civil português: I: parte geral - Coisas (incluindo domínio público, energia, teoria da empresa e tutela dos animais). 2. ed. Coimbra: Almedina, 2002. t. 2.

MESSINEO, Francesco. Manuale di diritto civile e commerciale: codici e norme complementari. 8. ed. Milano: Giuffrè, 1954. v. 3.

MIRAGLIA, Caterina. Divisione contrattuale e garanzia per evizione. Napoli: ESI, 1981.

MIRANDA, Francisco Cavalcanti Pontes de. Tratado de direito privado: parte especial. reimpr. atual. por Vilson Rodrigues Alves. Campinas: Bookseller, 2005. t. 38.

MONTEIRO, Washington de Barros. Curso de direito civil: direito das coisas. 38. ed. atual. por Carlos Alberto Dabus Maluf. São Paulo: Saraiva, 2007. v. 3.

Curso de direito civil: direito das obrigações: 2. parte. 34. ed. atual. por Carlos Alberto Dabus Maluf e Regina Beatriz Tavares da Silva. São Paulo: Saraiva, 2003. v. 5.

MOSCO, Luigi. Gli effetti giuridici della svalutazione monetaria. Milano: Giuffrè, 1948.

NUSDEO, Fabio. Curso de economia: introdução ao direito econômico. 3. ed. São Paulo: RT, 2001.

PEREIRA, Caio Mário da Silva. Instituições de direito civil: introdução ao direito civil; teoria geral do direito civil. 21. ed. atual. por Maria Celina Bodin de Moraes. Rio de Janeiro: Forense, 2005. v. 1.

Instituições de direito civil: teoria geral das obrigações. 21. ed. atual. por Guilherme Calmon Nogueira da Gama. Rio de Janeiro: Forense, 2008. v. 2. 
Instituições de direito civil: Contratos. Declaração unilateral de vontade. Responsabilidade civil. 12. ed. atual. por Regis Fichtner. Rio de Janeiro: Forense, 2006. v. 3.

PLANIOL, Marcel; e RIPERT, Georges. Traité pratique de droit civil français: contrats civils: première partie. 2. ed. par Joseph Hamel (vente); François Givord et André Tunc (louage). Paris: LGDJ, 1956. t. 10.

RICCA-BARBERIS, Mario. Trattato della garanzia per evizione: parte generale. Torino: Giappicchelli, 1958.

RIZZO, Nicola. Il problema dei debiti di valore. Padova: CEDAM, 2010.

RODRIGUES, Sílvio. Direito civil: dos contratos e das declarações unilaterais de vontade. 30. ed. São Paulo: Saraiva, 2007. v. 3.

RUBINO, Domenico. La compravendita. In: CICU, Antonio; MESSINEO, Francesco. Trattato di diritto civile e commerciale. 2. ed. Milano: Giuffrè, 1971. v. 23.

SACCO, Rodolfo. Il possesso. In: CICU, Antonio; MESSINEO, Francesco; e MENGONI, Luigi. Trattato di diritto civile e commerciale. Milano: Giuffrè, 1988. v. 7.

SANTOS, João Manuel de Carvalho. Código Civil brasileiro interpretado. 7. ed. Rio de Janeiro São Paulo: Freitas Bastos, 1964. v. 15.

SAVATIER, René. Cours de droit civil. 2. ed. Paris: LDGJ, 1949. t. 2.

SCADUTO, Gioacchino. I debiti pecuniari e il deprezzamento monetario. Milano: Valardi, 1924. In: PALAZZO, Antonio (a cura di). Gioacchino Scaduto - Diritto civile: opere monografiche. Perugia: Dipartimento per gli studi giuridici Alessandro Giuliani, 2002. t. 1.

SILVA, Clóvis Couto e. A obrigação como processo (1969). reimpr. Rio de Janeiro: FGV, 2006.

TALAMANCA, Mario. Vendita (diritto romano). In: Enciclopedia del diritto. Milano: Giuffrè, 1993. v. 46.

TEIXEIRA DE FREITAS, Augusto. Esboço do Código Civil. 3. ed. Brasília: Ministério da Justiça, 1983. v. 2.

TUCCI, Giuseppe. Garanzia. In: Digesto delle discipline privatistiche: sezione civile. Torino: UTET, 1992. v. 8.

VILLELA, João Baptista. Contribuição à teoria do valor dos bens na colação hereditária. 1964. Tese (Livre-Docência) - Universidade de Minas Gerais, Belo Horizonte.

WALD, Arnoldo. A cláusula de escala móvel. São Paulo: Max Limonad, 1956.

Direito das obrigações: teoria geral das obrigações e contratos civis e comerciais. 15. ed. atual. por Semy Glanz. São Paulo: Malheiros, 2001.

Tullio Ascarelli, o direito monetário e o direito bancário (uma visão brasileira inspirada no Código Civil). In: AZEVEDO, Antonio Junqueira de; TÔRRES, Heleno Taveira; CARBONE, Paolo 
(Coord.). Principios do novo Código Civil brasileiro e outros temas: homenagem a Tullio Ascarelli. São Paulo: Quartier Latin, 2008.

WAYAR, Emesto. Evicción y vicios redhibitorios: Evicción en los contratos en particular. Vicios redhibitorios. Parte general. Buenos Aires: Astrea, 1992. v. 2.

YARSHELL, Flávio Luiz. Evicção e denunciação da lide no novo Código Civil: contribuição ao direito bancário. Revista de direito bancário e do mercado de capitais, São Paulo, n. 26, ano 7. out./ dez. 2004. 